Florida State University College of Law

Scholarship Repository

Scholarly Publications

Fall 2010

\title{
Framing Change: Cause Lawyering, Constitutional Decisions, and Social Change
}

Mary Ziegler

Florida State University College of Law

Follow this and additional works at: https://ir.law.fsu.edu/articles

Part of the Constitutional Law Commons, and the Litigation Commons

\section{Recommended Citation}

Mary Ziegler, Framing Change: Cause Lawyering, Constitutional Decisions, and Social Change, 94 MARQ. L. REV. 263 (2010),

Available at: https://ir.law.fsu.edu/articles/336

This Article is brought to you for free and open access by Scholarship Repository. It has been accepted for inclusion in Scholarly Publications by an authorized administrator of Scholarship Repository. For more information, please contact efarrell@law.fsu.edu. 


\title{
FRAMING CHANGE: CAUSE LAWYERING, CONSTITUTIONAL DECISIONS, AND SOCIAL CHANGE
}

\author{
MARY ZIEGLER ${ }^{*}$
}

This article contends that current critics of change-oriented litigation assume a particular model of the relationship between law and social change: law is argued to mirror popular mores, and judicial decisions are thought at most to suppress unusual or outlying laws. This model is incomplete, because judicial decisions may help to change how a social cause is defined and labeled. In presenting a supplementary model, I argue that judicial decisions reframe debates, privileging some arguments, marginalizing others, altering the coalitions on either side, and influencing the types of legal reform those coalitions are able to pursue.

A series of state decisions on same-sex marriage had such a framing effect, advancing an equality-based frame, downplaying arguments about the immorality of homosexuality and the necessity of defending marriage, and creating opportunities for gay rights activists to build alliances with civil rights organizations. Similarly, Roe v. Wade deemphasized population control arguments and made it easier for the pro-choice movement to win the support of civil or minority rights leaders.

By drawing on these historical examples, I claim that litigation may sometimes offer benefits not available through direct action protest: litigation may make it less strategically risky for cause lawyers to advance multiple, competing frames of an issue at the same time, and judicial decisions may provide a strategically low-cost way for social movements to publicize a new definition of a cause. By altering the definition of a cause in this way, a judicial decision may create an environment more favorable to change.

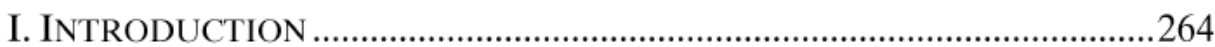

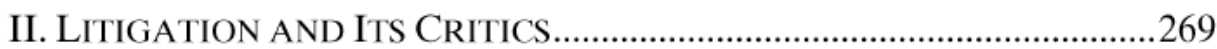

A. The Problems With Litigation ....................................................2270

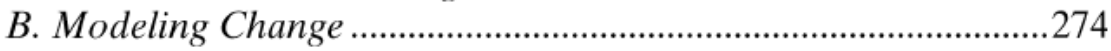

* Mary Ziegler is an Assistant Professor of Law at St. Louis University, and would like to give special thanks to Reva Siegel, Robert Post, Michael Klarman, William Eskridge, Bob Gordon, and Kenneth Mack for their insightful comments on earlier drafts. 
1. The Reflectionist Hypothesis.............................................274

2. The Cause-Acceptance Hypothesis......................................275

3. The Clean-Up Hypothesis.....................................................2276

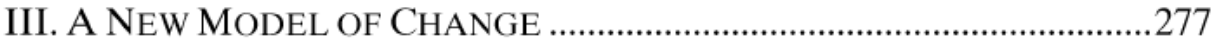

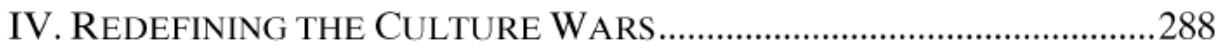

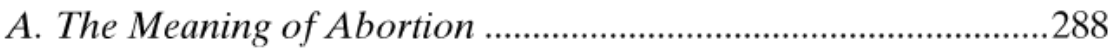

1. Lowering the Costs of Dissent ..........................................289

2. Changing Argumentative Strategies .................................292

3. Changing Alliances ..........................................................293

4. Changing Policy Possibilities..............................................294

B. The Meaning of Same-Sex Marriage ……..................................295

1. Lowering the Cost of Dissent................................................299

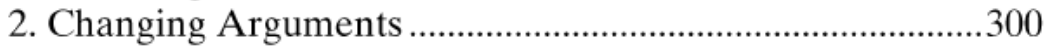

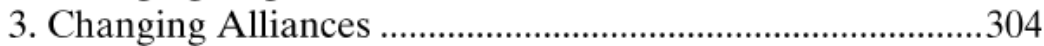

4. Changing Policy Possibilities?.................................................305

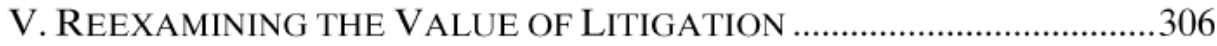

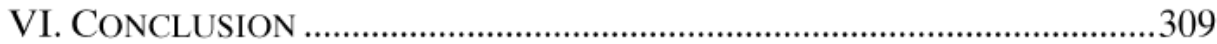

\section{INTRODUCTION}

The struggle for same-sex marriage has provoked the most recent crisis of confidence in constitutional litigation as a tool for social change. In the wake of California's passage of Proposition Eight, a referendum overruling a state decision striking down bans on same-sex marriage, a familiar set of concerns and complaints has resurfaced. ${ }^{1}$ Some have

1. For coverage of the impact of Proposition Eight and the controversy it generated, see Janet Kornblum, Gay Marriage Backers Step Up Protests, USA ToDAY, Nov. 14, 2008, at 3A. Recent debate about the value of change-based litigation echoes an earlier debate about what Abram Chayes called "public law litigation." See generally Abram Chayes, The Role of the Judge in Public Law Litigation, 89 HARV. L. REV. 1281, 1288-1304 (1976). Scholars like Chayes and Owen Fiss proposed that litigation could be used to challenge the structure of public schools, prisons, and other public institutions by generating broad remedies and monitoring institutional compliance. See id. at 1302-04; Owen Fiss, Foreword: The Forms of Justice, 93 HARV. L. REV. 1, 18, 28, 44 (1979). Early critics of public law litigation primarily questioned whether the courts had the institutional competence to craft the kind of remedies described by Chayes. See, e.g., Alexander M. Bickel, The Supreme Court And the IDEA OF PROGRESS 134 (1970). Recent scholarship has proposed alternatives to the style of change-oriented litigation stressed by Fiss and Chayes. Charles Sabel and William Simon propose a kind of "experimentalist" public law litigation, in which the courts: (1) destabilize existing practices and institutional arrangements by legitimating a plaintiff's claim; (2) create general performance standards for the parties; and (3) act as monitoring bodies to ensure institutional accountability. See Charles F. Sabel \& William H. Simon, Destabilization Rights: How Public Law Litigation Succeeds, 117 HarV. L. REV. 1015, 1035-36, 1076 (2004). Jules Lobel has suggested that social movements can use the courts as a forum for protest. See 
questioned the courts' institutional capacity to generate change, either because they cannot ensure that their rulings will be enforced ${ }^{2}$ or because they cannot change the beliefs of those whose views determine the course of policy. ${ }^{3}$ Others emphasize the ways in which litigation has

Jules Lobel, Courts as Forums for Protest, 52 UCLA L. RFV. 477, 479-80 (2004).

2. See Gerald N. Rosenberg, The Hollow Hope: Can Courts Bring About SOCIAL CHANGE? 10-21, 336-43 (2d ed. 2008). It is also worth noting the importance of an carlicr body of scholarship focused on the limits of "rights talk" as a tool for social change. Prior historical work on the civil rights and labor movements had suggested that social movements, and the civil rights movement in particular, prioritized litigation, legal rights, and other court-driven change. See, e.g., MARK TUSHNET, THE NAACP's LEGAL STRATEGY AGAINST SEGRFGATFD EDUCATION, 1925-1950, at xi (1987) (focusing on the legally driven aspects of civil rights strategy and detailing debates about litigation tactics); see also RICIIARD KLUGLR, SIMPLE IUSIICL: TIIIL HISTORY OI BROWN V. BOARI OH EDUCATION AND BLACK AMERICA's STRUGGLE FOR EQUALITY (1975). In the 1970 s and 1980s, scholars like Lani Guinier, Mark Tushnet, and William Forbath suggested that rights-oriented litigation is incffective, diverts resources from progressive goals, and reinforces existing institutional arrangements. See, e.g., WILLIAM E. Foriza I'II, LAW AND THIL SIIAPING OI: T1IL AMLRICAN LABOR MOVEMLNI 7-8, 167-77 (1991) (tracing how labor law changed and moderated the labor movement's ideology and strategies); Alan Freeman, Antidiscrimination Law from 1954 to 1989: Uncertainty, Contradiction, Rationalization, Denial, in THF PoI.ITICS OF LAW: A Progrfssivf. CRITIQUf: 285, 285 (David Kairys cd., 3d cd. 1998); Lani Guinicr, From Racial Liberalism to Racial Literacy: Brown v. Board of Education and the InterestDivergence Dilemma, 91 J. AM. HIST. 92, 116-18 (2004). This Article focuses on more recent criticism of change-oriented litigation for several reasons. First, arguments about the courts" institutional inability to deliver change have influenced the work of those who have recently followed Tushnet and Forbath. See, eg., Tomiko Brown-Nagin, Elites, Social Movements, and the Law: The Case of Affirmative Action, 105 CoI.uM. L. Rf. . 1436, 1520, 1527-28 (2005); Beth Van Schaack, With All Deliberate Speed: Civil Human Rights Litigation as a Tool for Social Change, 57 V $\Lambda$ ND. L. REV. 2305, 2307 (2004). By analyzing these newer arguments, I show that some scholars assume an important relationship between the courts' institutional capacity and the effects of litigation on social movement idcology and efficacy. Sccond, as we will see, in the wake of institutional arguments like those made by Rosenberg, scholars studying change-oriented litigation have more often made a set of assumptions about the relationship between law and social change. Focusing on more recent criticism allows me to foreground and criticize these assumptions.

3. See Michael J. Klarman, Brown and Lawrence (and Goodridge), 104 Micl. L. RLV. 431, 478-79 (2005) (explaining that backlashes are averted only when mosi Americans are already willing to accept a result). Of course, several scholars have responded that same-sex marriage litigation has some bencfits. See, e.g., WII.JAM N. ESKRIDGF, JR., EQUAI.ITY PRACIICE: CIVIL UNIONS AND TIIL FU'TURL OI GAY RIGIITS 26, 45 (2002) (explaining that marriage litigation has inspired gay rights activists and has helpfully raised expectations); see also D ANIEL R. PINELLO, AMERICA'S STRUGGLE FOR S $\triangle$ ME SEX M ARRI Thomas M. Keck, Beyond Backlash: Assessing the Impact of Judicial Decisions on IGBT Rights, 43 LAW. \& SOC'Y. RFV. 151, 158-60 (2009). Kcck has most recently argued that judicial decisions: (1) put same-sex marriage on state and national legislative agendas; (2) "push[ed] the policy envelope" in such a way as to make previously "radical" proposals seem "moderate;" (3) provided cover for legislators sympathetic to the LGBT cause; and (4) created constituencies willing to tolerate or support same-sex marriage. Id. at 158-60. Keck argues that judicial decisions create new constituencies by showing the public that same-sex marriage does not have negative societal effects. Id. at 159-60. Once a decision is in place, 
de-radicalized social movements, since courts favor moderate, legally grounded arguments that may enforce the social status quo. ${ }^{4}$ Although they focus on the value of litigation as a tool for change, critics of change-oriented litigation also offer a powerful account of the relationship between social change and judicial decision-making. In this account, as we will see, law is argued to affect neither the concrete enforcement of rights nor popular opinion about the justice of a movement's arguments.

In this Article, I challenge this view of the relationship between law and social change, and I reexamine arguments on the shortcomings of litigation. By critically evaluating these arguments, we can derive the basic premises of a model shared by litigation's critics of how social change occurs. The first premise of this model addresses the relationship between law and social change. Litigation's critics reason that legal reforms almost inevitably mirror shifts in social mores and popular opinion. This is the reflectionist hypothesis: law reflects but does not reshape public attitudes and views. The second premise addresses how social change happens. This is the cause-acceptance hypothesis: social change occurs when a majority of the public accepts the legitimacy of the movement's complaint. A final premise concerns law's relevance to social movement campaigns. This is the clean-up hypothesis: court decisions matter only when they strike down already unusual and unpopular laws or implement remedial measures the public already supports.

By offering an alternative account of the relationship between legal and social change, this Article complicates current accounts of how legal and social change relate to one another. Contrary to what is suggested by the reflectionist hypothesis, decisions and change-oriented litigation may sometimes produce social change indirectly, by redefining a social practice like same-sex marriage and thereby influencing citizens' attitudes. This model is one of "constitutional framing," whereby

the public sees that it has nothing to fear, and popular support for same-sex marriage increases. By contrast, constitutional framing creates new coalition-building opportunitics by changing how the public defines a grievance.

4. See ESKRIDGE, supra note 3, at 206-223 (surveying progressive or queer-theory arguments against same-sex marriage litigation); see also MICHAFI. WARNFR, THF. TROUBI.F. With Normal: Sfix, Poiltics, And Thf. EThics of QUfFer Liff (1999). Other critics sympathetic to the same-sex marriage movement have criticized organizers' focus on litigation by pointing to the backlash it creates. See, e.g., CRAIG A. RIMMERM $\Lambda$, FROM IDENTITY TO POLITICS: THE LESBIAN $\Lambda$ ND G $\Lambda$ Y MOVEMENTS IN THE UNITED ST $\Lambda$ TES 78 (2002); John D’Emilio, Will the Courts Set Us Free? Reflections on the Campaign for SameSex Marriage, in T11L POLITICS OI: SAML SLX MARRIAGL 39 (Craig A. Rimmerman \& Clyde Wilcox eds., 2007). 
movements, countermovements, and officials in constitutional debates compete and collaborate in changing or reinforcing the meaning of social practices.

The changing definition of a movement's cause may have effects more complex than the outcomes and shifts in public attitudes on which litigation's critics focus. When the prevailing meaning of a practice changes, a decision can alter the argumentative strategies adopted by opposing movements, the alliances each side can pursue, the policy opportunities available to competing groups, and the ways in which a movement can influence popular opinion. The framing effects of a decision may favor progressive social movements or conservative countermovements. In either case, constitutional framing demonstrates that social change occurs not only when members of the public accept the justness of a progressive or conservative movement's cause, but also when the public redefines that cause in a way that favors change.

Finally, contrary to what is suggested by the clean-up hypothesis, I contend that movements may sometimes benefit from using litigation rather than ordinary protest tactics to advance a particular frame. Because litigation can foster the expression of alternative arguments, the courts offer movements an opportunity to present a variety of possibly effective frames. When it does not yet have political influence, a movement may often have to rely on the media to publicize a frame. In such a case, movements have reason to silence dissent, for the media are likely to focus on internal divisions once they are discovered rather than on the movement's message. Consequently, social movement organizations may press members to speak with a single voice and to suppress alternative frames. By contrast, in applying rules governing pleading and the submission of amicus briefs, the courts may foster forms of dissent that would prove too costly for movements in the political arena.

Because high-salience, controversial decisions attract media coverage, litigation may offer a strategically low-cost way for movements to publicize a new frame. As we will see, movements that have not yet attracted the support of legislators often turn to the media to publicize a frame of a group's cause. However, social movement scholarship suggests that direct media coverage of movement protests may be strategically risky. If the movement appoints a spokeswoman, the appointed leader may gradually become unaccountable to the group she represents. A similar risk is involved if a movement chooses no leader to spread its message and hopes simply to promote a frame through public protest. In such cases, the media may themselves choose a leader or interpret a frame in a way contrary to a movement's 
interests. If litigation generates a high-salience judicial decision, that decision may offer a less strategically risky way for a movement to publicize a frame. Media coverage of high-salience decisions encourages the public to debate the merits of a decision's reasoning and result. When discussion focuses on a different set of questions, the prevailing meaning of a movement's cause may change as well.

Part I sets the stage for a reconsideration of the relationship between legal and social change. Because skepticism of litigation as a means of social change has become an important theme in contemporary constitutional scholarship, Part IA begins by focusing on several leading critics of change-oriented litigation: Michael Klarman, Gerald Rosenberg, Tomiko Brown-Nagin, and William Eskridge. Part IB sketches a model of the relationship between legal and social change set forth in the otherwise different work of these theorists.

The remainder of the Article develops a complementary model. Part II briefly sketches an alternative understanding of the relationship between legal and social change. By focusing primarily on the courts' ability to enforce constitutional rights or increase popular approval of a movement's cause, this Part argues that litigation's critics fail to capture important effects of judicial decisions on political debates.

Part III elaborates on the model described in Part II by studying the history of two major battles in contemporary culture wars: abortion and same-sex marriage. I focus on these case studies not because framing effects always advance progressive causes; there is reason to believe that judicial decisions have often reframed important debates in a way that advances conservative countermovement causes. ${ }^{5}$ Instead, I examine these examples because they often are cited as evidence of the shortcomings of change-oriented litigation.

Currently, we often take for granted that these debates address whether abortion involves a woman's right to choose or whether samesex marriage involves the gay citizens' right to equal treatment. However, the history studied in Part III shows that these frames were not always in place. In a series of litigation battles before and after Roe, movement dialogue downplayed population-control frames and forged a woman's-rights frame similar to the one familiar to us today. In creating

5. See, e.g., Reva B. Siegel, Equality Talk: Antisubordination and Anticlassification Values in Constitutional Struggles Over Brown, 117 HARV. L. REv. 1470, 1500-33 (2004) (tracing how judicial decisions like Milliken $v$. Bradley II and Loving v. Virginia publicized a conservative, anticlassification frame that became prominent in political debates about scgrcgation and busing); Reva B. Sicgel, The Right's Reasons: Constitutional Conflict and the Spread of Woman-Protective Antiabortion Argument, 57 DUKL L.J. 1641, 1641-48, 1658-70 (2008) (showing how Gonzales v. Carhart publicized a woman-protective antiabortion frame). 
an equality-based frame, state judicial decisions on same-sex marriage helped to deemphasize frames stressing the legitimacy of homosexuality as a lifestyle or emphasizing the unique social value of marriage.

Drawing on this history, Part IV shows that change-oriented litigation may serve not only to produce victory for individual clients or to generate precedent favorable to a movement's reform agenda. Litigation may also change what a movement's cause is understood to be. By using the historical narrative offered in Part III, I show that litigation's critics have missed important avenues of change sometimes available through litigation. Judicial decisions may alter how movement grievances are labeled, defined, and debated. Of course, the receptivity of a court to a particular frame will vary depending on, among other things, the configuration of the court and the political climate in which a case is decided. But when a judicial decision helps to redefine a cause, the political environment may ultimately become more favorable to change. Framing teaches that we should be careful not to underestimate the benefits of litigation. While it may not convince anyone of the rightness of a movement's complaint, litigation may reshape the political climate in a way that makes change more possible.

\section{LITIGATION AND ITS CRITICS}

In recent years, criticisms of change-oriented litigation have been varied and profound." In this Part, I study several of litigation's major critics, drawing out a model of social change from which they build different arguments. Scholars of legal anthropology have openly debated the nature of the relationship between legal and social change. By contrast, litigation's critics work from an unstated and assumed account of this relationship. Part IA opens with an examination of leading criticisms of change-oriented litigation. While offering significantly different proposals, I argue that these scholars work from a shared model of the relationship between legal and social change. Part IB sketches this model and explores its major premises. If we examine and challenge the premises on which this model is built, we will be

6. See, e.g., Michael W. McCann, Reform Litigation on Trial, 17 L. \& SoC'Y REV. 715 , 715-17 (1993) (reviewing GeRALD N. RosenberG, THE Hollow Hope: CAN CourTs BRING ABOUT SOCIAI, CHANGF? (1991)) (tracing the cmergence of criticism of changcoricnted litigation).

7. See, e.g., Robert Post, Law and Cultural Conflict, 78 CHI.-KENT. L. REV. 485, 486-89 (2003) (summarizing positions taken in contemporary legal anthropology debate). According to Post, legal anthropology scholars traditionally argued that law reflects and enforces popular values. See id. More recently, l'ost suggests, other scholars have contended that law actually influences and helps to produce those values. See id. at $488-90$. 
better able to understand alternative, indirect routes to social change.

\section{A. The Problems With Litigation}

Gerald Rosenberg's landmark studies were among the first to propose that "court decisions are neither necessary nor sufficient for producing significant social reform." Rosenberg's main contribution has been to cast doubt not only on the courts' willingness to create social change but also on their ability to implement their decisions." Because they possess few tools to ensure compliance with their decisions, it is argued that courts are not able to create social change unless "their decisions are supported by elected and administrative officials." Rosenberg further argues that support from the public or political elites is necessary to gain sufficient popular support to implement broad social change. ${ }^{11}$

Rosenberg also examines an alternative, "extrajudicial" path of influence, by which court decisions "inspir[e] individuals to act or persuad[e] them to examine and change their opinions." ${ }^{, 2}$ In his analysis of Roe, for example, Rosenberg states a number of claims that could be made in favor of extrajudicial influence: an argument that the Roe Court "greatly influenced popular opinion in favor of abortion" or a claim that the courts "spurred women to form and join women's rights organizations and to raise large sums of money."13 Based on his analysis, Rosenberg finds no evidence in support of these claims. ${ }^{14}$

\section{ROSENBERG, supra note 2, a1 35.}

9. Roscnberg's account draws in part on the intuitions of legal mobilization scholars that "[t]he bounded nature of constitutional rights prevents courts from hearing or acting on many significant social reform claims." Id. at 13. For key examples of legal mobilization scholarship, see note 54 and accompanying text. In asserting that "Supreme Court decisions ... have seldom strayed far from what was politically acceptable," Rosenberg's argument also forcshadows the work of scholars like Barry Friedman. Id. at 13; accord Barry Friedman, Dialogue and Judicial Review, 91 MlC1I. L. RLv. 577 (1993); Barry Friedman, The Importance of Being Positive: The Nature and Function of Judicial Review, 72 U. CIN. L. RLV. 1257, 125759 (2004). Rosenberg has elaborated his argument about courts' inability to produce social change on scveral occasions. See, e.g., Gerald N. Rosenberg, Courting Disaster: Looking for Change in All the Wrong Places, 54 DRAKF. L. RFV. 795, 796 (2006) (arguing that the courts traditionally defend status and privilege instead of promoting social change); Gerald $\mathrm{N}$. Rosenberg, The Irrelevant Court: The Supreme Court's Inability to Influence Popular Beliefs About Equality (Or Anything Else), in REDEFINING EOUALITY 172, 172-88 (Neal Devins \& Davison M. Douglas cds., 1998) (arguing that the Court's decisions do not affect popular opinion about racial or gender equality).

10. ROSENBERG, supra note 2, a1 16.

11. Id.

12. Id at 7 .

13. Id. at 236,241 .

14. Id. at 241 . 
Like Rosenberg, Michael Klarman challenges the courts' institutional capacity to generate social change. Klarman highlights the backlash the courts may produce in the rare instances in which their opinions do not track popular opinion. He explains that, "[b]y outpacing public opinion on issues of social reform, such rulings mobilize opponents, undercut moderates, and retard the cause they purport to advance." 15

Moreover, Klarman reasons, there are few positive indirect effects of change-oriented litigation to offset costly backlashes. He acknowledges that judicial victories can have important symbolic value to a movement but questions whether decisions have any broader social impact. ${ }^{16}$ By raising the salience of an issue, the courts are argued to be able to "forc[e] many people to take a position [for the first time]." ${ }^{17}$ However, he contends, salience-raising fuels backlash and may thus harm rather than help the cause the courts endorsed. ${ }^{18}$ Moreover, he offers evidence that judicial decisions do not "influence the position" people take nor make them more "strongly committed to implementing the ruling."

Unlike Klarman, Tomiko Brown-Nagin focuses not on the courts' institutional incapacity, but instead on the adverse effects of changeoriented litigation on social movement efficacy and strategy. ${ }^{20}$ BrownNagin claims that social movements risk much by using constitutional law to define their campaigns. ${ }^{21}$ The courts will fail to deliver the change a movement demands because their decisions are often "moderate, elitist, and utilitarian," the product of negotiations among members of

15. Klarman, supra notc 3, at 482; see also Michacl Klarman, The Racial Origins of Modern Criminal Procedure, $99 \mathrm{MICH}$. L. RFV. 48, 96 (2000) (arguing that "the most significant effect of Brown $v$. Board of Education may have been neither its educational influence on white northerners nor its motivational impact on African Americans, but rather its crystallization of southern white resistance").

16. See Klarman, supra note 3 , at $481-82$.

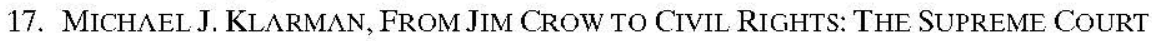
AND THF: STRUGGI.F. FOR RACIAI. EQUAI.ITY 364 (2004). It is worth distinguishing framing from what Klarman identifics as the salience-raising effects of judicial decisions. See id. By raising the salience of an issue, a decision forces people to take sides on an issue for the first time. See id. By contrast, framing often draws attention 10 a different aspect of an issue on which people have already taken a position and encourages them to reformulate their opinion on that basis.

18. See Klarman, supra note 3, at 473.

19. KIARMAN, supra note 17 , at 365 ; see also Michacl J. Klarman, Fidelity, Indeterminancy, and the Problem of Constitutional Fvil, 65 FORDHAM L. RFV. 1739, 1750 (1997) (finding to be contestable the proposition that Supreme Court opinions educate "public opinion ... in a positive direction").

20. Brown-Nagin, supra notc 2 , at 1439.

21. See, e.g., id. 
the elite and their effort "to find consensus amidst cultural conflict.",22

In her view, these outcomes illustrate how social movements are fundamentally in tension with constitutional law and litigation. ${ }^{23}$ Law demands that movements de-radicalize, play by institutional rules, and make only those demands that law would recognize. ${ }^{24}$ If movements define themselves by litigation, she argues, they lose their ability to challenge existing policy compromises ${ }^{25}$ Only when public attitudes change noticeably can movements effectively pressure the government to recognize the legitimacy of their claims. ${ }^{26}$

By comparison to Brown-Nagin, William Eskridge suggests that even definitional litigation campaigns can have both benefits and costs to social movements. He shows that movements and law have a dialectical relationship: movements propose doctrines and constitutional revolutions that the courts adopt, albeit often in modified form. ${ }^{27}$ In turn, constitutional law "influence[s] the rhetoric, strategies and norms of social movements." ${ }^{2 /}$ In Eskridge's view, law helps to define and even create identity-based social movements, first by enforcing discrimination against them and then by giving "concrete meaning to the "minority group' itself." 29 Later, law gives identity-based social movements a chance to demand social change $\mathrm{e}^{30}$ and permits them to reemerge as mass political mobilizations. ${ }^{31}$

In Eskridge's account, however, some litigation campaigns and judicial decisions have a negative impact both on social movements and on the larger society. As one key example of such a campaign, Eskridge points to Roe v. Wade. ${ }^{32}$ Eskridge asserts that Roe announced abortion rights in a "politically insensitive way" by acting before political consensus about abortion rights had been reached. ${ }^{3 *}$ For this reason,

22. Id. at 1479, 1487; see Tomiko Brown-Nagin, Race as Identity Caricature: A Local legal History Lesson in the Salience of Intraracial Conflict, 151 U. PA. L. RFV. 1913, 1916 (2003).

23. Brown-Nagin, supra note 2 , at $1442,1489$.

24. See id. at 1511.

25. Id. at 1511 .

26. Id. at 1527 .

27. See William N. Eskridge Jr., Some Effects of Identity-Based Social Movements on Constitutional Law in the Twentieth Century, 100 MICH. L. REV. 2062, 2065-67 (2002).

28. William N. Eskridge Jr., Channeling: Idenity-Based Social Movements and Public Law, 150 U. PA. L. RLv. 419, 423 (2001) [hereinafter Channeling].

29. Id. at 422.

30. See id.

31. See id. at 459-60.

32. 410 U.S. 113 (1973).

33. Channeling, supra note 28, at 520; see also William N. Eskridge Jr., Pluralism and 
Roe "undermine[d]" abortion rights "by stimulating extra opposition to" them. ${ }^{34}$

While often carefully exploring the benefits of some change-oriented campaigns, Eskridge's work suggests that those campaigns should be limited. He implies that "constitutional law can change if a longstanding political equilibrium is destabilized, and it must change if the public culture settles into a new political equilibrium." not in place, a favorable judicial decision may damage the movement whose cause has been embraced and generate "immediate and longstanding political turmoil." ${ }^{36}$

In different ways, and for different reasons, litigation's critics argue that social movements should not invest limited resources in changeoriented litigation. For example, Rosenberg argues that changeoriented litigation "may not be the best use of scarce resources in important battles for significant social reform." ${ }^{37}$ If the courts follow popular opinion and are institutionally incapable of changing it, as Klarman's account suggests, social movements should focus on changing popular opinion by direct-action protest. He speaks for others in stating that litigation alone "cannot fundamentally transform a nation." 38

Disirust: How Courts Can Support Democracy by Lowering the Stakes of Politics, 114 YAI.F. L..I. 1279, 1312-13 (2005) [hereinafter Pluralism].

34. See Channeling, supra note 28 , at 520.

35. Id. at 500 .

36. See Pluralism, supra note 33, a1 1282-83.

37. ROSFNBFRG, supra note 2 , at 246.

38. KLARMAN, supra note 17 , at 468. 


\section{B. Modeling Change}

Critics of litigation offer deeply different arguments about the effects of constitutional litigation on movement strategy and the shortcomings of litigation as a tool for change. However, Their arguments proceed from a shared account of the relationship between legal and social change. This model of change rests on a set of hypotheses about how law relates to social change, how social change occurs, and how law can serve change campaigns. If we understand these hypotheses, we can begin to develop an alternative model of social change.

\section{The Reflectionist Hypothesis}

As we have seen, litigation's critics question whether constitutional decisions can deliver the social changes a movement seeks. These claims all follow in part from the hypothesis that law reflects public mores, attitudes, and values. For example, Brown-Nagin writes: "It is only after such [public] attitudinal $\mathrm{c}[\mathrm{h}]$ anges occur or are under way that lawyers might successfully seek changes in law. ${ }^{39}$ Eskridge also reasons "constitutional law can change [only] if a longstanding political equilibrium is destabilized." This is the reflectionist hypothesis: a claim that law reflects popular values, opinions, and mores.

Constitutional framing challenges the hypothesis that law only reflects popular mores and opinions about a movement's cause. It proposes that, under some circumstances, constitutional decisions and litigation can also redefine a movement's cause and reshape debate about it. Much will depend, for example, on whether the public views abortion as an issue of women's rights or as a gender-neutral public health crisis. When a decision helps focus debate on a different set of policy questions in this way, it may change which questions are discussed, alter which arguments are used, reshape the coalitions addressing a movement's grievance, and determine which goals these coalitions are likely to achieve. In this way, constitutional framing can make change more possible.

39. Brown-Nagin, supra note 2 , at 1527.

40. Channeling, supra note 28, at 500; see also ROSENBERG, supra note 2, at 16 (arguing that the courts will not be able to enforce their decisions unless a movement wins "popular support to implement their decisions"); Klarman, supra note 3, at 482 (cxplaining that backlashes occur because the courts cannot change popular opinion and in fact undermine movement causes when decisions "outpac[e] public opinion"). 


\section{The Cause-Acceptance Hypothesis}

If law cannot create social change, how do litigation's critics believe social change occurs? The model underlying otherwise different criticisms of litigation suggests an answer. First, a group of people must recognize and articulate a shared grievance. ${ }^{41}$ That movement then develops a repertoire of effective protest tactics, such as marches, media events, advertisements, lobbying, or sit-ins. ${ }^{42}$ This effort is a political one that unfolds outside of court. ${ }^{43}$

Social change ultimately happens when popular opinion recognizes the legitimacy of a movement's complaint. For example, Brown-Nagin explains that social change is possible only when "public attitudes... changed substantially and noticeably, so much so that the media recognize and confirm the shift in opinion" and public officials are pressured to act. $^{4+}$ Rosenberg suggests that legislative and judicial action on abortion became possible when "opinions on abortion ... changed rapidly." "Klarman similarly measures social change in race relations by studying public opinion shaped by "deep-seated social, political, and economic forces." ${ }^{46}$ This is the cause-acceptance hypothesis: social change occurs only when movements in the political arena convince the public that their cause is legitimate.

However, we can better understand how popular opinion changes by looking at more than mere disapproval or approval of a practice. ${ }^{47}$ Instead, constitutional framing proposes that attitudes toward a practice will depend on which questions are central to a debate. An issue like

41. See, e.g., Brown-Nagin, supra note 2, at 1504.

42. See Cilarles 'illly, SOCial MOVlemlents, 1768-2004, at 1-14 (2004) (discussing movements' political protest repertoire); see also Jo Freeman, A Model for Analyzing the Strategic: Options for Social Movement Organizations, in WAVES OF PROTEST: SOCIAL MOVFMFNTS SINCF: THF. SIXTIFS 221, 226-27 (Jo Frceman \& Victoria Johnson eds., 1999) (explaining the tactics of formally organized social movement organizations); Eric Hirsh, Sacrifice for the Cause: Croup Processes, Recruitment, and Commitment in a Student Social Movement, in WAVES OF PROTEST, supra, at 47,47-57 (explaining blockade tactics).

43. See, e.g., Brown-Nagin, supra note 2, at 1508 ("[P] instances of insurgent political activity ... that are unmediated by the state.").

44. Id. at 1527 .

45. ROSLNBLRG, supra note 2, at 265; see also Channeling, supra note 28 , at 501-03 (explaining that social change occurs when a new "national consensus develops").

46. Michacl J. Klarman, Brown, Racial Change, and the Civil Rights Movemen, $80 \mathrm{VA}$. L. RFV. 7, 10 (1994).

47. Cf. Robert Post, Law Professors and Political Scientists: Observations on the Law/Politics Distinction in the Guinier/Rosenberg Debate, 89 B.U. L. REV. 581, 583 (2009) (arguing that theory about the irrelevance of judicial decisions vicws law as influential "only when its substance is widely known or only when it is a necessary or sufficient cause for measurable changes in public opinion"). 
same-sex marriage or abortion will involve several, sometimes conflicting, policy considerations. A citizen's opinion will depend in part on which of those considerations is given the most weight. After all, we would not be surprised if someone were more willing to oppose global warming when environmental damage was highlighted than she would when the cost of reducing carbon emissions was stressed. When shifting the meaning of a movement's cause and the public debate about it in this way, constitutional litigation and decisions can help to create a political environment that favors change.

\section{The Clean-Up Hypothesis}

The final and arguably most important question addressed by litigation's critics involves the role that litigation and law can play in creating social change. Leading criticisms suggest that while litigation alone cannot deliver the social changes movements demand, the courts can strike down outliers, and produce and elaborate on remedies already supported by popular consensus. Rosenberg acknowledges that "litigation can remove minor but lingering obstacles," and he suggests that court-delivered remedies can be part of a "mopping-up operation." ${ }^{48}$ Eskridge also explains that, once a national consensus develops in favor of a result, "the Court will become part of the clean-up process." Klarman often asserts that the Court's decisions reflect the general "propensity of constitutional law to suppress outliers," and Brown-Nagin agrees that movement attorneys must "mobilize outside the law before attempting to change society through law in the courts." This is the clean-up hypothesis: a proposal that the courts can do little more than strike down unpopular decisions or create enforceable rules and remedies once popular opinion has shifted in a movement's favor.

Constitutional framing demonstrates that constitutional law and litigation can sometimes play a broader and more complex role than the clean-up hypothesis suggests. Framing shows that judicial decisions not only strike down unpopular laws but also produce environments that favor political change. After a high profile decision, debate will turn in

48. See Rosfnbfri, supra notc 2 , at 427.

49. Channeling, supra note 28, at 501; see also Klarman, supra note 3, at 445 (explaining that Brown and Lawrence did "support] movements that had already acquired significant momentum"); of. Brown-Nagin, supra note 2, at 1516-21 (suggesting that movements may, with varying degrees of success, use litigation to inspire movement members while focusing on protest and public persuasion).

50. Klarman, supra note 3 at 483.

51. Brown-Nagin, supra note 2, at 1445; see also Michael J. Klarman, Rethinking the Civil Rights and Civil Liberties Revolutions, 82 VA. L. RLV. 1, 16-17 (1996). 
part on whether the Court reached the right conclusions on the issues it addressed. When the Court brings attention to new issues, its decision may refocus and reshape popular debate. When addressing a different question about abortion or same-sex marriage, movements and countermovements may be able to make different claims, win different kinds of members, build new alliances, and pursue different kinds of legislative reform.

Constitutional framing offers a supplemental understanding of the relationship between legal and social change. In this model, movements, countermovements, and officials engage in dialogic framing struggles, contesting and collaborating to determine which issues will be central to a case. When the courts adopt or modify one of these frames, the resulting decision may raise awareness about important constitutional issues that would not otherwise have received political consideration or attention. When debate refocuses on these different issues, the political climate for change may have shifted in a movement's favor.

Criticisms of litigation assume that law reflects social mores. What alternative does constitutional framing propose? How does this alternative model operate in practice? Part III turns to these questions.

\section{A NEW MODEL OF CHANGE}

In 1960, in the wake of the backlash that followed the Court's decision in Brown v. Board of Education, ${ }^{52}$ legal scholar Charles Black, Jr. proposed that the courts influenced social change not by encouraging the public to see the flaws in laws declared to be unconstitutional but instead by legitimating laws that were upheld. ${ }^{53}$ Black suggested that, by upholding new policies, the courts could at least reinforce legal and political change. ${ }^{5+}$ Since the time Black was writing, we have seen that a growing body of scholarship has cast doubt on the validity of even Black's modest proposal. As Keith Whittington has recently put it, "The Court appears to be more likely to reinforce existing cleavages in public opinion than to build consensus behind policies that it validates."

52. 347 U.S. 483 (1954).

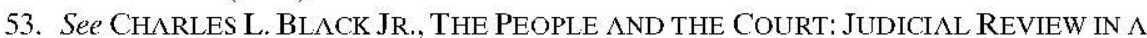
DFMOCRACY $52(1960)$.

54. See id. (arguing that the Supreme Court "has acted as the legitimator of the government").

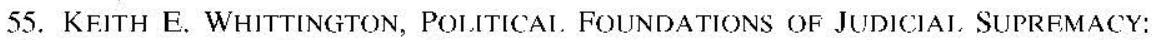
IIIL P'RLSIDLNCY, TIIL SUPREML COURT, AND CONSTTTUTIONAL LEAdLRSIIIP IN U.S. HISIORY 153 (2007). By contrast, legal-mobilization theorists argue that, while change- 
Why are litigation's critics so adamant that law only reflects popular attitudes? The answer may lie in part in how these scholars measure social change. Litigation's critics first focus on measurable shifts in popular attitudes. $^{56}$ These measurements serve two purposes for critics of change-oriented litigation. First, critics like Rosenberg have contended that the public is unaware of controversial decisions and their content. $^{57}$ If people do not know what the court has said, a judicial decision is unlikely to produce change. Other critics argue that, although the public is aware of controversial opinions, judicial decisions still have no effect on public attitudes. ${ }^{58}$ The courts are argued to be unable to convince people to accept the legitimacy of causes that the public formerly rejected. ${ }^{59}$ Moreover, as Brown-Nagin emphasizes, the courts are attracted to compromise and are thus unlikely even to promise the kind of change movements seek. ${ }^{60}$

The second primary measurement used by litigation's critics involves the courts' ability to enforce the rights they announce. ${ }^{61}$ That the "[c]ourts ... have neither the purse nor the sword," as Martin Shapiro writes, is well understood. ${ }^{62}$ Because courts are also argued to be incapable of altering popular acceptance of a practice, judicial decisions are thought not to encourage public compliance with or official enforcement of a decision.

oriented litigation has drawbacks, it nonetheless inspires movement members, making social change seem more possible, offering members important organizing skills, and serving as a rallying symbol for activists. See, e.g., JOFi, F. HANDI.F, SOCIAI. MOVFMFNTS AND THF LLGAL SYSILM: A TIILORY OI: LAW RLIORM AND SOCIAL CIIANGL 188 (1978); MICIIALL W. MCCANN, RIGIITS AT WORK: PAY EQUIT'Y RLI ORM AND TIIL POLITICS OI LEGAL Mobiliz $\Lambda$ TION 48 (1994); STUART A. SCHEINGOLD, THE POLITICS OF RIGHTS: LAWYERS, Pubi.lc Poilcy, and Poidtical. ChangF 139-41 (2d ed. 2004); Marc Galanter, The Radiating Effects of Courts, in EMPIRICAI. THFoRIFS ABOUT COURTS 117, 125-26 (Kcith O. Boyum \& Lynn Mather eds., 1983); Michael McCann \& Helena Silverstein, Rethinking Law's "Allurements": A Relational Analysis of Social Movement Lawyers in the United States in CAUse L $\Lambda$ Wyering: Political Commitments $\Lambda$ ND Profession $n$ L Responsibilities 261, 261-92 (Austin Sarat \& Stuart Schcingold cds., 1998).

56. See Post, supra note 47, at 583.

57. See Gerald Rosenberg, Romancing the Court, 89 B.U. L. RFV. 563, 566-67 (2009) (explaining that most Americans cannot cxplain the holding of Roe and arguing that this fact provides evidence that "most Americans do not have a clue as to what the Court is doing or has done").

58. See, e.g., infra notes 59-60.

59. See, e.g., KLARMAN, supra note 17, at 367 (arguing that the Supreme Court has not "educated" the public to support the outcome of its decisions on issues like the death penalty and abortion).

60. See supra text accompanying notes $20-21$.

61. See, e.g. Rosfnberg, supra note 2 , at 10-21.

62. Martin Silapiro, Colstis: A Comparativl and POlITICAL Analysis 13 (Paperback ed. 1986). 
These measurements offer useful insight into some aspects of our legal system. Recent empirical studies have shown that judicial decisions sometimes have no measurable impact on popular opinion, as was the case when the Court struck down a flag-burning ban in Texas $v$. Johnson. . $^{3}$ Other studies suggest that the Court's decisions increase elite support, as was the case with the Court's death-penalty decisions in the $1970 \mathrm{~s}^{64}$ These examples indicate that the outcome-based measurements used by litigation's critics offer valuable information about the relationship between legal and social change. But because they focus primarily on these indications of social shifts, litigation's critics offer a fundamentally incomplete account of the relationship between law and social change.

This account is inadequate partly because it considers only whether public approval or disapproval of a cause shifts, not how or why such shifts occur. In recent years, "sociolegal" scholars have suggested one way that law influences popular attitudes: by structuring the way citizens understand the world around them. ${ }^{65}$ This explanation draws on crossdisciplinary work about what Erving Goffman first labeled framing: "frameworks of understanding available in our society for making sense out of events." Framing an issue is a way of defining, labeling, and understanding it.

Complex constitutional issues like the availability of legal abortion or the legalization of same-sex marriage can be defined in a number of different ways. For example, we may know that the "pro-choice" movement favors broader rather than narrower access to legalized abortion. Hypothetically, however, we could imagine a number of

63. Peter Hanson, Flag Buming, in Publ.IC Opinion And Constitutional. CONTROVliksy 184, 199 (Nathan Persily et al. eds., 2008) ("In the two decades since Texas v. Johnson, public opposition to flag burning has not changed.").

64. John Hanley, The Death Penally, in PUBI.IC OPINION, supra note 63, at 180, 135 ("In the 1970s, the Supreme Court appears to have had an impact on opinion, bolstering antideath penalty sentiment among more-educated Americans ....").

65. See, e.g., Paul Schiff Berman, The Cultural Life of Capital Punishment: Surveying the Benefits of a Cullural Analysis of Law, 102 CoIUM. L. RFV. 1129, 1140 (2002) (essay revicw) (arguing that legal discourse offers a framework "through which individuals in society come to apprehend reality"); Austin Sarat, Redirecting Legal Scholarship in Law Schools, 12 Y ALL J.L. \& HuMAN. 129, 134 (2000) (book review) (explaining that law helps 10 constitute citizens' daily experiences "by providing the principal catcgories in terms of which social life is made to secm largely natural, normal, cohesive, and coherent"). Although it describes the ways in which law can help people to label and understand their experiences, sociolegal scholarship does not per se address the relationship between legal and social change or discuss the value of cause-based litigation, as constitutional framing does.

66. Erving GOliman, Framl AnAlysis: An ESSAy ON TIIL ORGanization ol EXPLRILNCL 10 (2d ed. 1986). 
reasons why the movement had this goal. Some reasons may appeal to us more than others and make us more likely to tolerate or even endorse a cause.

A growing body of scholarship confirms that the framing of a group's cause is central to its ability to win recruits, ${ }^{67}$ to sustain protest,${ }^{68}$ and to influence how other groups and bystanders view that event or cause. $^{69} \quad$ As social movement scholar Doug McAdam explains, "successful framing efforts are almost certain to inspire other groups to reinterpret their situation." ${ }^{, 0}$ Because so much is at stake in the framing of an issue, social movements often compete in dialogue with one another to frame an issue. ${ }^{71}$ These framing campaigns may play a key role in determining what kinds of social change are possible. By convincing members of the public that one's definition of a cause is the right one, movements take an important step in creating support for that cause. $^{72}$ In this sense, social movement scholarship reflects common

67. See, e.g., David A. Snow \& Doug McAdam, Identity Work Processes in the Context of Social Movements: Clarifying the Identity/Movement Nexus, in SELF, IDENTITY, AND SOCIAL MOVEMENTS 41, 52-53 (Sheldon Stryker et al. eds., 2000) (arguing that before individuals become willing to "act on behalf of and in concert with a movement-it is necessary that their personal identities dovetail with a movement's collective identity"); Verta Taylor \& Nancy E. Whittier, Collective Identity in Social Movement Communities: Lesbian Feminist Mobilization, in Frontiers IN SOCIAL MOVEMENT THEORY 104, 105 (Aldon D. Morris \& Carol McClurg Mueller eds., 1992) (arguing that "identity construction processes are crucial to grievance interpretation in all forms of collective action"); see also WILLIAM A. GAMSON, TALKING POLITICS 84-86 (1992) (explaining the importance of identity and cause-framing to collective action); Russell J. Dalton et al., The Challenge of New Movements, in CHALLENGING THE Political Order: NeW Social and Political MOVEMENTS IN Western DEMOCRACIES 1, 3-22 (Russell J. Dalton \& Manfred Kuechler eds., 1990) (explaining the importance of identity and cause-framing to collective action).

68. See, e.g., John A. Noakes, Official Frames in Social Movement Theory: The FBI, HUAC, and the Communist Threat in Hollywood, in FRAMES OF PROTEST: SOCIAL Movements AND THE Framing Perspective 89, 89-90 (Hank Johnston \& John A. Noakes eds., 2005) (explaining the importance of effective framing to movement emergence and growth).

69. See infra note 70 and accompanying text.

70. Doug McAdam, Culture and Social Movements, in New Social Movements: FROM IDEOLOGY TO IDENTITY 36, 42 (Enrique Laraña et al. eds., 1994).

71. See, e.g., Sidney G. TARRow, Power in Movement: Social Movements And CONTENTIOUS POLITICS 110 (2d ed. 2002) (describing framing contests as struggles for "cultural supremacy"); Doug McAdam et al., Introduction, in COMPARATIVE PERSPECTIVES ON SOCIAL MOVEMENTs 1, 16 (Doug Adams et al. eds., 1996) (describing framing battles as involving "intense contestation between ... the movement, the state, and any existing countermovement").

72. See, e.g., Joseph R. Gusfield, The Reflexivity of Social Movements: Collective Behavior and Mass Society Theory Revisited, in NEW SOCIAL MOVEMENTS, supra note 70, at 58,69 ("Awareness that norms and meanings are at issue and in contestation is itself a step in the development of change."). 
lessons in legal advocacy about the central importance of effectively framing an issue or question. To frame an issue correctly, as one legal writing manual advises, is to begin persuading the judge to decide the issue in your client's favor. ${ }^{73}$ By publicizing a different definition of a group's cause, in turn, a judicial decision may create an environment that favors change.

Litigation's critics neglect this dimension of social change. If we follow some of litigation's critics in looking only at approval or disapproval of a practice, we will miss the beginnings of changes in public attitudes. As social movement scholar Joseph Gusfield explains, the framing of a cause can create "the recognition that some accepted pattern of social life is now in contention." $" 74$

Thus far, I have suggested that judicial decisions sometimes change the social meaning of movement causes. By focusing public attention on a different issue, a controversial decision can reshape the social meaning of a cause. However, there is also reason to think that, in some cases, movements will benefit from using litigation rather than ordinary protest tactics in advancing a frame.

The first and less controversial advantage of litigation involves the relative costs of dissent in court. If they lack the ability to influence a legislature, movements using direct action protest tactics to generate official support must often rely heavily on the media to publicize a frame or "mobiliz[e] popular support." As social movement scholar Doug McAdam has explained, "The simple fact is that most movements lack the conventional political resources possessed by their opponents and thus must seek to offset this power disparity by appeals to other parties. The media has come to be seen-logically, in my view-as the key vehicle for such influence attempts." promote a frame directly, through working to attract media coverage of a group's protest activities, or indirectly, through obtaining a high-

73. See HLllin S. Silapo lit Al., Writing ANd ANAlysis in Till LaW 305 (4th ed. 1999) (stressing the importance of "framing the question so that it suggests a response in [one's] [avor").

74. Gusficld, supra note 72 , at 70.

75. Doug McAdam, The Framing Function of Movement Tactics: Strategic Dramaturgy in the American Civil Rights Movement, in COMP $\Lambda \mathrm{R} \Lambda \mathrm{TIVE}$ PERSPECTIVES, supra note 71, at 338,345 . William Gamson has argued that "the mass media arena is the major site of contests over mcaning." William A. Gamson, Bystanders, Public Opinion, and the Media, in THF. BlaCKWlll COMPanion T'O SOCial MOVlimlin's 242, 243 (David A. Snow et al. eds., 2004).

76. Doug McAdam, Movement Strategy and Dramaturgic Framing in Democratic States: The Case of the American Civil Rights Movement, in DLLIBLRATION, DLMOCRACY AND TIIL MLdIA 117, 125 (Simone Chambers \& Anne Costain eds., 2000). 
salience judicial decision that publicizes a frame.

Social movement scholarship points to strategic risks associated with using direct media coverage. When there are intense struggles within movements regarding cause or identity, a movement may lose control of its message, as "this internal movement conflict can easily become the media's story" and focus." Social movement scholars Todd Gitlin and Patricia Bradley have shown that the media diluted the messages of the Feminist and New Left movements in this way by focusing not on the frame presented by a group but on internal divisions within it. ${ }^{78}$ Consequently, formally structured "social movement organizations" often suppress a rich variety of competing frames in order to present an image of unity and to exercise control over the frame that the media will cover. $^{79}$ In mounting an effective political or media campaign, movements are pressured to speak with one voice. In the process, other important views within a movement may not be heard by the public.

By comparison, litigation may sometimes offer movements a better chance to promote diverse frames. As we have seen, an effective political or media strategy may require a movement to silence dissenting members, at least in public debate. By contrast, the Federal Rules of Civil and Appellate Procedure, like those in many states, foster a form of dissent. Like many state equivalents, Federal Rule of Civil Procedure 8 (d) invites "hypothetical" and "inconsistent" claims." Liberal pleading rules of this kind may encourage litigants to present a richer variety of frames. Most state and federal courts also accept or invite the submission of amicus briefs. ${ }^{81}$ Thus, amici without the resources or

77. See, e.g., Gamson, supra note 75 , at 252.

78. See, e.g., Patricia Bradify, Mass Mfdia and thf Shaping of american FFMINISM 1963-1975, at 253 (2003) (showing that media coverage of the feminist movement gradually focused on "internal divisions" rather than the frame promoted by movement leaders); TODD GITLIN, TIIL: WIIOLL WORLD IS WATCIIING: MASS MLDIA IN TIIIE MAKING $\Lambda$ ND UNM $A$ KING OF THE NEW LEFT 114-15 (1980) (examining how media coverage of divisions within the New Left student movement undermined the group's ability to spread its messagc). There is reason to belicve that social movements and conservative countermovements would face similar risks, since "[i]nternal rivalries can attract attention to a movement, but the coverage is about the rivalry, not issues and events" relevant to the movement. STEPHANIE GRECO L $\Lambda$ RSON, MEDI \& MINORITIES: THE POLITICS OF R $\Lambda$ CE IN NFWS AND ENTERTAINMFNT 149 (2006).

79. See, e.g., Gamson, supra note 75 , at 247 ("[Clompetition among frames within a movement about which one should be promoted and emphasized is one major component of a frame-critical analysis of movements.").

80. See Fld. R. Civ. P. 8(d); see also 5 Cilarlls Alan Wrighit \& Artilur R.

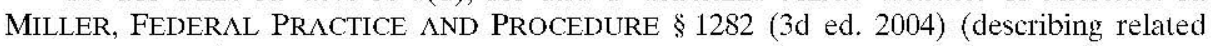
state approaches).

81. The relevant rules on the submission of amicus briefs may appear restrictive. United States Supreme Court Rule 37, for example, requires that an amicus brief "bring[] to the 
organization to mount a test case will still often be able to present a frame to the court.

Second, the courts may lower the costs of broadcasting a frame to the public. By attracting media attention, a controversial judicial decision can increase public awareness of that subject and encourage the public to debate the questions addressed by a court. ${ }^{82}$ Of course, recent scholarship has questioned whether judicial decisions in fact raise the salience of particular issues. Frederick Schauer has contended that controversial opinions do little to shape the nation's political agenda or policy priorities. $^{83}$ More recently, Rosenberg has pointed to evidence that the public is not able to identify controversial decisions or describe their reasoning. ${ }^{84}$

But even if we assume these claims to be correct, there are other ways that judicial decisions may raise awareness of an issue and offer an effective way to publicize a movement's frame. In particular, social movement scholarship has documented the importance of media coverage to the success of a movement's framing efforts. ${ }^{8.5}$ As social movement scholar William Gamson explains, the media offer a valuable opportunity for "[a]dvocacy groups that are relatively poor in conventional resources and limited in access to decision-makers" to publicize a frame. ${ }^{\gamma_{6}}$ A movement may attempt to attract media attention for its frame in a number of ways: by winning the attention of relevant elected decision-makers, recruiting a charismatic leader, or staging a dramatic event or protest.

attention of the court relevant matter[s] not already brought to attention by the parties...." SUP. CT. R. 37; see also FF.D. R. APP. P. 29 (requiring consent of the partics for the submission of amicus bricfs). In practice, however, the courts are generally liberal in accepting amicus briefs. See, e.g., 4 AM. Jur. 2D Amicus Curiae $\$ 6$ (2007) (explaining that "the trend, particularly in appellate courts, is to accept and even invite the participation of amici curiae"); Ruben J. Garcia, A Democratic Theory of Amicus Advocacy, 35 FLA. ST. U. L. REV. 315, 326 (2008) (showing that "courts do not often reject amicus bricfs").

82. For arguments that controversial decisions raise the salience of issues, see, for example, Klarman, supra note 3, at 473 and Margare1 Meriwether Cordray \& Richard Corday, Setuing the Social Agenda: Deciding to Review High-Profile Cases at the Supreme Couri, 57 U. KaN. L. RFV. 313, 313 (2009).

83. See Frederick Schauer, Foreword: The Court's Agenda-And the Nation's, 120 HARV. L. REV. 4, 11-12 (2006).

84. See supra note 57 and accompanying text.

85. See, e.g., Jeremy D. Mayer, Introduction to MEdi^ Power, MEdi^ Politics 1,10 (Mark J. Rozell \& Jeremy D. Mayer eds., 2d ed. 2008) ("The media's most invidious power is the ability to control what gets reported and whose voice is heard in that story"); Gamson, supra note 75, at 254 (emphasizing the central importance of media access to successful framing efforts).

86. Gamson, supra note 75 , at 254.

87. See, e.g., Donatella Della Porta \& MArio Dinni, Socinl Movemements: 
However, social movement scholarship identifies costs that accompany each of these strategies. Advocacy groups that do not have the resources or organization to lobby elected officials will have difficulty convincing public decision-makers to advance a particular frame. $^{8.8} \quad$ A movement faces a different set of difficulties when speaking through a charismatic leader or using dramatic protest tactics. As Todd Gitlin has documented in his studies of the New Left, charismatic leaders capable of promoting a frame may become media celebrities who are no longer accountable to the movement. ${ }^{39}$ Similarly, when a movement stages dramatic protests and chooses not to put forth a leader, the group may risk losing the ability to promote its own frame and may "invit[e] the media to designate who will speak for the movement." "\%"

When the Supreme Court announces a controversial decision that adopts or modifies a movement's frame, that decision may lower the strategic cost of publicity for a movement. Although the Court receives substantially less coverage than do the other branches of government, the media pay significant attention to dramatic decisions on divisive issues. $^{91} \quad$ In particular, studies of press coverage of the Supreme Court show that the media publicize judicial work product, including the frame of an issue that the Court adopts. ${ }^{92}$

Of course, the likelihood that a court will adopt a particular frame may depend on a number of factors, including the political leanings of the judges hearing a case and the popular climate surrounding a decision. However, when a high-salience decision attracts media attention, a blockbuster decision may also encourage officials and social movement leaders to focus on the result and justification offered by the court. As different issues become the center of debate, citizens may

AN INI RODUCION 178 ( $2 \mathrm{~d}$ ed. 2006) (describing the use of guerilla theater and direct action protest to promote a movement's frame); Gamson, supra note 75, at 187 (emphasizing the recruitment of a leader as a tool to publicize a movement's frame).

88. See Gamson, supra note 75 , at 254 .

89. See GitLIN, supra nole 78 , at $148-80$.

90. Gamson, supra notc 75 , at 252 .

91. See Doris A. GRABER, MAss Medi $\Lambda$ ND AMERICAN POLITICs 289 (7th ed. 2006) (arguing that, while the press relatively infrequently covers the courts, judicial decisions make news when the Court addresses emotional issues or subjects that have major consequenees for the political system).

92. Mayer, supra note 85, at 9 (stating that some scholars believe press coverage of the Court is "almost entirely focused on the Court's work product"); see also ELLIOT E.

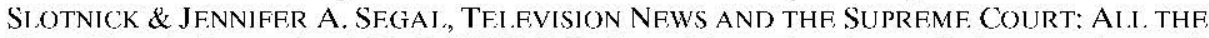
NLWS TIIA'T'S FIT TO AIR? 10, 13 (1998) (offering evidence that the media focus on the result of a decision and the public reaction to it). 
come to define an issue differently.

When a decision helps to assign a different meaning to a movement's cause, the argumentative strategies and alliance-building opportunities available to either side may shift as well. Regents of California v. $B a k k e,{ }^{9.3}$ the Court's first major affirmative action decision, had such a framing effect. Before Bakke, in the mid-1970s, affirmative action was often primarily discussed in tandem with busing as a denial of free choice. ${ }^{94}$ Opponents of both practices like New York Senator James Buckley, rising Republican Patrick Buchanan, the conservative Young Americans for Freedom, and African-American economist Thomas Sowell made similar arguments against both policies." Like busing, affirmative action was argued to deny black and white families "freedom of choice." Like busing, affirmative action was also seen to be the work of an "intrusive government" that claimed the "right and the ability to move people around like they were blocks of wood." "In turn, proponents of affirmative action characterized both busing and affirmative action as tools necessary to achieve racial integration. ${ }^{9 *}$ As NAACP Chief Counsel Nat James explained, those opposed to busing or "special admission" affirmative action programs were thought to be focused on "complicat[ing] the process of desegregation."

Instead of focusing on this integration-based frame, Justice Powell's influential concurrence in Bakke distinguished impermissible "quota" programs from constitutional affirmative action programs that used race only as a "plus' in a particular applicant's file." suggested that it was wise to distinguish acceptable and unacceptable

93. 438 U.S. 265 (1978) (plurality).

94. For examples of this phenomenon, see, for example, Congressman Calls Affirmative Action 'Just Plain Wrong', N.Y. Times, Oct. 3, 1977, at 25 and Steven V. Roberts, Longtime Allies on Rights Split by Bakke Case, N.Y. TIMES, Sep1. 25, 1977, a1 1.

95. See, e.g., Patrick Buchanan, Discrimination in Reverse, C1ll. T'RIB., Oct. 26, 1975, at A6; Philip Hager, Bakke Wins but Justices Uphold Affirmative Action, L.A. 'IIMLS, June 29, 1978, at 1 (explaining views of the leaders of Young Americans for Freedom); Thomas Ronan, Buckley Says Tendency to Create 'Quota Society' Threatens Nation, N.Y. TimFs, Scpt. 9, 1976, at 47 (reporting Senator Buckley's opinion that affirmative action and busing had to be barred in "nearly every sphere of employment and educational endeavor"); Thomas Sowell, A Black 'Conservative' Dissents, N.Y. TIMES, Aug. 8, 1976, at 14.

96. The Busing Issue Boils Over, TIMF, MAG., Fcb. 28, 1972, available at http:/www.timc .com/time/magazine/article/0,9171,905830,00.html (last visited Dec. 18, 2010); see also Sowell, supra note 95 , at 15 .

97. Sowcll, supra note 95 , at 15. 14.

98. See William Wong, Reverse Discrimination Revisited, WALL SI. J., Dec. 21, 1976, at

99. Glen Elasser, Rights Pendulum Swung Too Far?, CHI. TRIB., Mar. 6, 1977, at 8.

100. Regents of the Univ. of Cal. v. Bakke, 438 U.S. 265, 317 (1978) (plurality). 
affirmative action. As importantly, Powell's Bakke concurrence offered a frame for affirmative action that differed significantly from earlier integration-based accounts, a frame based on the importance of individual consideration and the unique harmfulness of group classification.

In the aftermath of Bakke, discussion gradually focused not on the proper tools used to achieve integration but instead on which affirmative action programs, if any, were not "quotas." 101 As Bakke shifted the terms of debate, the coalitions discussing the issue were, for a time, reshaped as well. Before Bakke, Republican leaders often denounced all affirmative action as "sex and race quotas." decision, the Reagan Administration endorsed "race neutral affirmative action," distinguishing between programs mandating preferential treatment for individuals and those "anticipated to result in improved opportunities for deprived individuals, a disproportionate number of whom may be members of minority groups.",104

Brown similarly reshaped political debate about segregation. As Michael Klarman has documented, it was possible before Brown for racial moderates to support segregation without endorsing white supremacy. ${ }^{105}$ Politicians like Big Jim Folsom and Lyndon Johnson were able to combine race-equality rhetoric and gradual racial reform with clear support for school segregation. ${ }^{106}$ By equating support for segregation with rejection of racial equality, Brown helped to radicalize

101. Morris Abram, a civil rights leader and prominent opponent of affirmative action, argued in favor of "remedial action" such as job training for the disadvantaged, as an alternative to quotas. See, e.g., David A. Drachsler, What's All This About 'Quotas'?, WAsil. Post, Aug. 7, 1983, at C8 (arguing that opponents of affirmative action used the "quota" label as a tool in generating opposition); Jack Rosenthal, Editorial, Morris Abram, LBJ, and Neutrality, N.Y. TIMFs, July 17,1983 , at 20 E. Even pollsters began focusing on public vicws of "quotas" versus other forms of affirmative action. See Lindsey Gruson, Survey Finds $73 \%$ Oppose Racial Quotas in Hiring, N.Y. T'ImLs, Sept. 25, 1983, at 29.

102. Before Bakke, George H.W. Bush, then Chairman of the Republican Party, denounced all affirmative action in this way. Lou Cannon, GOP Reform Group Cheers Bush's Stand Against Quotas, WASII. POS1, Sept. 12, 1973, at A2.

103. See Tom Sherwood, U.S. Justice Official Rejects Racial Quotas as Quick Fix for Bias, WASH. Post, Oct. 6, 1983, at B10. By the winter of 1983 , however, civil rights groups were already arguing that the Reagan Administration opposed all affirmative action. See Milton Coleman, Administration Asks Blacks to Fend for Themselves, WAS11. P'OSI, Dec. 5, 1983, at A1, A8.

104. Affirmative Action and Equal Protection: Hearing on S.J. Res. 41 Before the Subcomm. on the Constitution, of the S. Comm. on the Judiciary, 97th Cong. 2 (1981) (statement of Sen. Orrin Hatch, Chairman, Subcomm. on the Constitution).

105. See KIARMAN, supra note 17 , at $386-87$.

106. See id. 
debate and to redefine segregation as a practice inextricably linked to white supremacy. ${ }^{107}$

A quick glance at the framing effects of Bakke and Brown suggests that, by redefining a movement's grievance, a judicial decision may benefit either a progressive social movement or a conservative countermovement. Of course, in most instances, when the courts address low-salience issues, there will be no observable framing effects. ${ }^{108}$ In other cases, the reframing of an issue has both costs and benefits for those on either side of a debate. After Bakke, for instance, the realignment of coalitions made it more difficult to maintain federal legislation imposing quotas for the hiring of minority construction workers. ${ }^{109}$ At the same time, Bakke temporarily increased support for "quota alternatives," such as voluntary or incentivized efforts to recruit minority candidates. ${ }^{110}$ In other cases, as with the radicalization of Southern politics after Brown, a decision may redefine a cause in a way that works primarily in a countermovement's favor, at least in the short term.

By redefining an issue, a judicial decision may set back or advance a campaign for change. However, the normative point to be taken from constitutional framing is that litigation can still matter to a change campaign. In spite of the concerns raised by critics like Rosenberg and Klarman, it may still be worthwhile for movements to use their resources on litigation, even early in a struggle. In some cases, litigation may be able to reshape the meaning of a movement's cause in a way that ordinary politics cannot.

How may judicial decisions redefine a cause in practice? Because critics of change-oriented litigation often focus on battles in the contemporary culture wars, Part IV reexamines the history of two important struggles involving abortion and same-sex marriage. If we examine how the arguments and coalitions in these debates have changed over time, we may come to a different understanding of the role of litigation as a tool for change.

107. See id.

108. See Schauer, supra note 83 , at 50 (arguing that the Court's docket consists primarily of low-salience issues).

109. The Reagan Administration madc a particular point of targeting "quotas," see Fred Barbash, Administration Urges Court Ban on Quotas, WASH. POST, Dec. 3, 1983, at A4, as did Orrin Hatch's proposed amendment to ban some forms of affirmative action. Kathy Sawyer, Senate Panel Starts Ilearings on Constitutionality of Affirmative Action, WASH. PosT, May 5, 1981, a1 A2.

110. See, e.g., Sherwood, supra note 103 , at B10 (relating support of the Reagan Administration's approval of "race neutral affirmative action"). 


\section{REDEFINING THE CULTURE WARS}

Critics of change-oriented litigation suggest that social movements go to court seeking to win acceptance for their cause. ${ }^{111}$ However, as we will see, there is more than one reason to go to court. Part A examines how the definition of the abortion-legalization cause evolved after Roe. We have come to associate pro-choice politics with debate about a woman's right to choose abortion. Before Roe, this frame was often less prominent than those involving physicians' rights and population control. Roe helped to marginalize claims about population growth, and the decision helped to focus new attention on claims about women's reproductive autonomy and equal citizenship.

Part B evaluates the history of the same-sex marriage movement and the evolving definition of its cause. In recent years, we have come to take for granted that the same-sex marriage debate turns on demands for equal treatment and civil rights. However, this frame was not always in place. In the mid-to-late $1990 \mathrm{~s}$, national anti-gay organizations framed the discussion as a referendum on the legitimacy of homosexuality as a lifestyle, and national gay rights groups instructed their members not to describe the issue as one of sexual-orientation discrimination. In a series of decisions, state supreme courts stressed equality- or civil-rights rhetoric when defining the same-sex marriage cause. Partly in response, we will see that gay rights organizations began emphasizing equality-based claims to a greater extent than they had before. At the same time, as the terms of the debate shifted, opponents of same-sex marriage reshaped their own arguments in response, first deemphasizing open condemnation of homosexuals and later downplaying defense-of-marriage contentions.

This history shows that judicial decisions like Roe and Goodridge $v$. Department of Public Health ${ }^{112}$ did not simply fail to educate the public or trigger backlashes. Instead, these decisions also drew public attention to a different set of questions. As public debate focused on a new subject, the meanings of each struggle changed as well.

\section{A. The Meaning of Abortion}

Today, Roe is arguably best known for creating backlash. ${ }^{1.3}$ As we will see, however, the decision played an equally important role in

111. See, e.g., Brown-Nagin, supra note 2, at 1442-43.

112. 798 N.E.2d 941 (Mass. 2003).

113. See Robcrt Post \& Reva Sicgel, Roc Rage: Democratic Constitutionalism and Backlash, 42 HARV. C.R.-C.L. L. RLV. 373, 406 (2007) (arguing that concern about the backlash produced by Roe defines much progressive scholarship about the decision). 
redefining the abortion-legalization cause.

\section{Lowering the Costs of Dissent}

In important ways, the terms of the abortion debate before Roe did not resemble those likely to be familiar to most of us today, as prochoice activists often avoided the rights- or choice-based frames that now are taken for granted. Instead, groups like the National Abortion Rights Action League (NARAL) were equally likely to adopt population-control frames of the abortion issue. For example, in the early $1970 \mathrm{~s}$, a handbook for pro-choice leaders published by NARAL advised activists to explain that "[t]he population explosion compels us to take every means necessary to curb our growth rate" and to contend that "since contraception ... seems insufficient to reduce fertility to the point of our growth, we should permit all voluntary means of birth control [including abortion]." Women (NOW) also began combining its arguments about women's decisional and physical autonomy with claims about the need for population control. ${ }^{115}$ After NBC aired an episode of the popular television program Maude involving abortion, Wilma Scott Heide, thenPresident of NOW, commented at a NOW press conference: "The pressure of populations on world food supplies is coming home to America." ${ }^{, 16}$

For the purpose of political organization and media strategy, leaders of groups like NOW and NARAL pressed members to suppress or downplay some claims about women's rights. For example, in 1969,

114. NARAL Spcaker and Debater's Handbook Excerpt (1972), in The NARAL Papers [hereinafter NARAL Papers] (on file with the Schlesinger Library, Harvard University). Conservatives within the pro-choice movement had strategic reasons for characterizing the abortion-legalization cause as one involving population control or genderneutral physicians' rights. Population control arguments associated abortion legalization with reforms that enjoycd bipartisan support in Congress, such as the bill creating a National Center for Population and Family Planning in the Department of Health, Education, and Welfare. See Ernest Ferguson, Zero Population Growth Isn't Zero, L.A. TImLs, Jan. 30, 1972, at 17. Another reason to rely on population-control or physicians'-rights arguments was the perceived radicalism or controversy associated with women's rights claims for abortion legalization. As Joseph Nellis of NARAL cxplained, "courts would more casily strike down state anti-abortion laws if the test case were presented in terms of interference with the physician's practice of medicine than if it were done on the basis that many women's rights groups have advocated-namely ... the right of a woman to control her own body." Eileen Shanahan, Doctor Leads Group's Challenge to Michigan Ant-Aborion Law, N.Y. TIMFS, October 5, 1971, at 28.

115. Memorandum from Wilma Scoll Heide 10 NOW Chapter Presidents, Task Force Coordinators, Board Officers, and Members (Jan. 31, 1972), in The Wilma Scoll Heide Papers [hereinafter Scott Papers] (on file with the Schlesinger Library, Harvard University).

116. Id. 
when NARAL formed to coordinate national efforts to repeal abortion bans, there were already deep divisions between feminists and other pro-choice leaders about how the abortion-legalization cause should be described to the public. ${ }^{17}$ At the first meeting of the organization's national Board of Directors, Betty Friedan, a founding member of NARAL and a prominent women's rights advocate, moved that NARAL "should support political groups working toward the basic purpose of the right of a woman to decide when to have or not have children." ${ }^{113}$ The motion died for lack of a second. ${ }^{119}$ At the same meeting, Larry Lader moved that NARAL resolve that, "to prevent increasing overpopulation, American parents in general ... should adopt the ... principle of the 2-child family." 120 The motion passed 2618 , as did another resolution intended to make clear that "men as well as women have the right to birth control."121

Even NOW pressed its members not to focus exclusively on a feminist abortion-legalization frame. In November 1970, Christopher Tietze of the Population Council asked Wilma Scott Heide, thenPresident of NOW and herself a demographer, if members of NOW who had had abortions would participate in a study on the health effects of abortion on women and the risk factors that would exacerbate those effects. ${ }^{122}$ In writing to NOW state affiliates who opposed participating, Heide disagreed, suggesting that "[t]he request from the Population Council represents the fact that we are viewed as responsible and stable." "123

The courts offered the pro-choice movement a place to test frames that movement leaders had sometimes downplayed in the political arena. Of course, several pro-choice briefs in Roe, including the one submitted on behalf of the American College of Obstetricians and

117. Myra MacPherson, Aborion Laws: A Call for Reform, WASH. PoST, Fcb. 17, 1969, at D1 (explaining early divisions among NARAL organizers). For history of the abortion reform and repeal movements in the late $1960 \mathrm{~s}$ and early $1970 \mathrm{~s}$, see generally, for example, D $\Lambda$ VID J. G $\Lambda$ RROW, LIBERTY $\Lambda$ ND SEXU $\Lambda$ LITY: THE RIGHT TO PRIV $\Lambda$ CY $\Lambda$ ND THE M $\Lambda$ KING OF ROF V. WADF 335-373 (1994); LFSIJF, J. REGAN, WHFN ABORTION WAS A CRIME: WOMFN, MFDICINF, AND LAW IN THE UNITF. STATFS, 1867-1973, at 216-46 (1997).

118. NARAL National Board of Directors Meeting Minutes (Sept. 28, 1969), 2, in NARAL Papers, supra note 114.

119. Id.

120. Id.

121. Id.

122. Letter from Christopher Tietze to Wilma Scott Heide (Nov. 5, 1970), in Scott Papers, supra note 115.

123. Wilma Scott Heide to NOW Board of Directors et al. (Winter 1970-1971), in Scott Papers, supra note 115 . 
Gynecologists and the American Psychiatric Association, still defined the abortion-legalization cause in line with current debate: as genderneutral, involving " $[\mathrm{t}]$ he rights of physicians to administer health care, and of patients to seek medical treatment."124 However, litigation allowed the feminist wing of the movement to promote a frame that the movement had not stressed in the political domain. Representing a number of women's liberation organizations, including NOW, attorney Norma Zarky entered into the Roe litigation in the hope that the Court would publicize and "reach the fundamental issue of a woman's rights." 125 In another amicus brief on behalf of feminist organizations, Nancy Stearns of the Center for Constitutional Rights explained that Roe offered women the chance to "raise aspects of the constitutional issues before the Court not raised by the parties," especially the equality interests of women involved in abortion legalization. ${ }^{126}$ As Stearns explained, reproductive control was central to women's ability to participate equally in society, for "it [was] the woman who [bore] the disproportionate share of the de facto and de jure burdens and penalties of pregnancy, childbirth, and child-rearing." 27

In drawing on these diverse frames, Roe forged a different definition of the abortion legalization cause. The decision did address the dominant definitions of the cause offered by physicians' groups and public health organizations. In early drafts and in its final version, Roe and its companion case, Doe v. Bolton, ${ }^{12 R}$ treated abortion legalization as an issue involving the mixed right of the woman and the physician, ${ }^{129}$ the right of "the physician, in consultation with his patient, . . . to determine, without regulation by the State, that, in his best medical judgment, the patient's pregnancy should be terminated."."1:3i!

However, the frame to emerge from Roe also incorporated the claims of feminist attorneys like Zarky and Stearns. As Zarky called for recognition of "a woman's fundamental right to decide for herself whether or not to have a child,"

124. See, e.g., Brief for the Am. Coll. of Obstetricians and Gynecologists et. al. as Amici Curiac Supporting Respondents, at 38, Roc v. Wadc, 410 U.S. 113 (1973) (Nos. 70-18, 70-40). 125. Lynn Lilliston, Women See Abortion as a Civil Right, L.A. TIMLS, Aug. 13, 1971, at F1; see, e.g., Women Ask Nationwide Abortion Legalization, L.A. TIMES, Aug. 12, 1971, a1 34. 126. Brief for New Women Lawyers et al. as Amici Curiac, Supporting Respondents, at 5, Roe, 410 U.S. 113 (Nos. 70-18, 70-40).

127. Id. at 6 .

128. 410 U.S. $179(1973)$.

129. See Roe, 410 U.S. at 153.

130. Id. at 163 .

131. See Lilliston, supra note 125 , at F1. 
constitutional "right of privacy ... is broad enough to encompass a woman's decision whether or not to terminate her pregnancy." ${ }^{1.32}$ In explaining why the abortion decision deserved constitutional protection, the Court also drew on Stearns' account of the unique burdens and anxieties facing women before and after childbirth. ${ }^{133}$ Significantly, population control was not made an issue in the Roe decision.

\section{Changing Argumentative Strategies}

Although a number of race-based and international scandals hurt the population control movement in the late $1970 \mathrm{~s},{ }^{134}$ Roe played an important role in deemphasizing population control arguments. After the decision, NARAL operatives were given the following instruction for participating in debates about abortion:

Allegation: That abortion should not be used as a means of population control. [Response]: Agreed.... In a democratic, nonsectarian society, women should be free to make their own decisions regarding childbearing and contraceptive use. The term 'population control' implies the use of coercive policies and programs to limit population growth. The United States has no such policy.

In the aftermath of Roe, pro-choice organizations began stressing rights-based instead of population control arguments. By 1974, NOW operatives were advised to compare "the Supreme Court['s] ... recogni[tion] of the federal constitutional basis for a woman's right to

132. Roe, 410 U.S. at 153 .

133. Id. In particular, the Cour1 explained: "Maternity, or additional oflspring, may force upon the woman a distressful life and future .... Mental and physical health may be taxed by child carc." $I d$.

134. Several developments in the mid-to-late $1970 \mathrm{~s}$ set back the movement for population control. In 1973, the revelation that 1wo African-American teenage girls in Alabama had been involuntarily sterilized created a scandal that set off a wave of lawsuits and accusations about stcrilization abusc and its connection to the population control movement. See Nadine Brozan, The Volatile Issue of Sterilization Abuse: A Tangle of Accusations and Remedies, N.Y. T'IMLS, Dec. 9, 1977, at B10. In the mid-1970s, Third World leaders, no longer willing to participate in population control programs, began arguing that population control policies had been motivated not by humanitarian concern but by racism or colonial cconomic interests. See, e.g., Population Parley of UN May Ignore Population Growth, WALl S'I. J., Aug. 27, 1974, at 32.

135. See Mary Zicgler, The Framing of a Right to Choose: Roc v. Wade and the Changing Debate on Abortion Law, 27 LAw \& HIST. RFV. 281, 317 (2009) (quoting NATIONAL ABORTION RIGIITS LEAGUL, LEGAL ABORTION: A SPLAKLE'S AND DLBATLR'S NOILBOOK $29(1978)$. 
limit childbearing" to the "freedom of religion or freedom of speech.",136 Similarly, following a strategy meeting in 1973, Planned Parenthood activists were told, "an important thematic idea to be stressed is that abortion in a pluralistic society is to be considered as a matter for determination according to personal choice." 137

\section{Changing Alliances}

As Roe helped to change the arguments made in the abortion debate, the decision also changed the alliances available to the prochoice movement. That African-Americans as a group at one point were more likely to oppose abortion than other groups is relatively wellknown. ${ }^{1.38}$ It is less well-documented that, before Roe, prominent African-Americans suggested that the abortion cause was unjust primarily because abortion was defined as an issue of population control. $^{139}$ For example, Marvin Davies, the Florida field secretary for the NAACP, stated that population control measures were not "in the best interests of the black people."

When Roe helped to redefine abortion as a choice- or rights-based issue, the pro-choice movement was more easily able to pursue alliances with African-Americans and civil rights leaders. Jesse Jackson, who had led a war against abortion, had described it as a threat to AfricanAmericans. ${ }^{14}$ But in 1983, when Jackson declared his intention to run for the Democratic presidential nomination, he promised feminist leaders to defend a woman's right to choose abortion. ${ }^{1+2}$

136. Abortion Amendment Strategy (1974), in Scott Papers, supra note 115 (on file with the Schlesinger Library, Harvard University).

137. See Zicgler, supra note 135, at 309 (quoting The Denver Conference Memorandum (Nov. 2, 1973), in NARAL Papers, supra note 114 (on file with the Schlesinger Library, Harvard University)).

138. Earlier sludies of popular opinion on abortion found a more pronounced difference in opinion between African-Americans and whites regarding abortion; when studics control for religiosity, a less mcaningful distinction has becn found. See Samantha Luks \& Michacl Salamone, Abortion, in PubLiC OPINION, supra note 63, at 80, 82-83.

139. See Robert McGilory, Opens Abortion War, CHI. DFF., Mar. 21, 1973, at 1 (describing opposition of Jessc Jackson to legalized abortion as a way to reducc population growth); Castellano Turner \& William A. Darity, Fears of Genocide Among Black Americans as Related to Age, Sex, and Region, 63 AM. J. P'UB. HLALTI 1029, 1029-34 (1973) (explaining concerns of African-American men and women about abortion when it was described as a method of population control).

140. Reactions Mixed to U.S. Birth Plan, N.Y. TimLs, July 19, 1969, at 9.

141. See McGlory, supra notc 139 , at 1.

142. Lee May, Jackson the Orator Has Become Jackson the Politician, L.A. TIMLS, November 27,1983 , at 1 . 


\section{Changing Policy Possibilities}

As Roe helped to reshape the alliances on either side of the abortion debate, it also helped to redefine the political opportunities available to each side. Between 1974 and 1980, as the fight over the scope of abortion funding bans became increasingly bitter, the pro-choice movement was able for the first time to rely on civil rights advocates in the Senate, like Ted Kennedy and Birch Bayh, to vote down the strict House proposals and to call for funding at the very least in cases of rape, incest, or medical necessity. ${ }^{143}$ In 1975 , for example, pro-choice leaders expected Kennedy to continue his long-standing, pre-Roe opposition to legalized abortion as a form of population control ${ }^{144}$ when the Senate voted on a Medicaid abortion restriction. ${ }^{145}$ Because the definitions of abortion had begun to change, Kennedy led the opposition to the restriction and ultimately helped to defeat it that year. ${ }^{1+6}$ After Roe, when debate focused on whether abortion was a constitutional or civil rights issue, leaders like Kennedy helped lead Senate opposition to strict Medicaid bans. ${ }^{147}$

Over time, as the new definition of the pro-choice cause became entrenched, Roe may also have helped to reshape popular opinion. There is reason to think that before Roe a significant number of African-Americans viewed the abortion-legalization cause as a population control measure. A February 1971 poll taken by the Chicago Defender found that while only $26.4 \%$ of African-Americans generally opposed abortion reform, $63.7 \%$ of those polled professed a belief that government-funded abortions could lead to "mass genocide in the black community." ${ }^{148}$

When Roe helped to redefine abortion as a choice- or rights-based issue, the pro-choice movement was more easily able to convince African-Americans and civil rights leaders to support legalized abortion. A published study on race and views on abortion confirms this view. ${ }^{149}$ A6.

143. See Stuart Auerbach, Kennedy Backs Abortion Aid, WASH. PosT, Apr. 11, 1975, at

144. See Nick Thimmesch, Abortion and the 1972 Presidential Race, CIII. T'RIB., July 25, 1971, at A5.

145. See Aucrbach, supra notc 143 , at A6.

146. See, e.g., id.

147. See, e.g., id.

148. See Blacks Split on Sex, CIII. DLI., February 15, 1971, at 1. Similarly, a 1972 study published in the American Journal of Public Health found that $51 \%$ percent of AfricanAmerican women polled believed that population growth was important for the survival of the race, and $37 \%$ were convinced that legalized abortion as a form of "black genocide" was a genuine threat. See Turner \& Darity, supra note 139, at 1029-34.

149. See Michael W. Combs \& Susan Welch, Blacks, Whites, and Attitudes Toward 
Controlling for a variety of factors likely to determine a person's views on abortion, including family income, years of education, region of residence, frequency of church attendance, and religious denomination, the study found that, in the two years before Roe, being AfricanAmerican was, in its own right, a statistically significant predictor that a person would be opposed to abortion reform. ${ }^{150}$ In the period three years after Roe, being African-American was no longer a statistically significant predictor of opposition to legalized abortion. ${ }^{151}$

Roe helped fundamentally to reshape the abortion debate. By helping to redefine the abortion-legalization cause, Roe shifted the argumentative strategies used by either side, the coalitions competing movements could form, and the policy opportunities that each side could pursue. Partly because of Roe, what had been a debate about population growth and physicians' rights was becoming a discussion about women's rights.

\section{B. The Meaning of Same-Sex Marriage}

The same-sex marriage struggle has served as the latest target for some critics of change-oriented litigation. Recent scholarship has suggested that state-level litigation has been counterproductive, triggering the passage of restrictive defense-of-marriage legislation and the election of socially conservative politicians. ${ }^{152}$ As we will see, however, litigation also helped to change the social meaning of same-sex marriage. In the mid-to-late 1990s, national organizations framed the issue as a referendum on the legitimacy of homosexuality or as a question about the importance of marriage that was unrelated to sexual orientation. Beginning with the Vermont Supreme Court's decision in Baker v. State, ${ }^{1,3}$ a series of state supreme court decisions helped to

Abortion, 46 Pив. OP. Q. 510, 510-19 (1982). Drawing on the pooled poll responses collected by the General Social Surveys (conducted by the National Opinion Research Center at the University of Chicago) between 1972 and 1980, the study examined the attitudes of blacks and whites with respect to abortion in three two-ycar periods (1972-74, 1975-77, and 1978$80)$. Id at $512-13$.

150. Id. at 518

151. Id. at 516. This result has becn confirmed by scveral recent studies of popular opinion on abortion. See, e.g., Jennifer Strickler and Nicholas L. Danigelis, Changing Frameworks in Attitudes Toward Abortion, 17 SOC. F. 187, 195, 197 (2002) (finding that, when similar controls were applied, African-Americans were more likely than whites to support abortion by the 1990s); Clyde Wilcox, Race Differences in Abortion Autudes: Some Additional Evidence, 54 PUB. OP. Q. 248, 248-55 (1990) (arguing that, when studies control for religiosity, African-American opinion about abortion was becoming more favorable in the 1980s).

152. See, e.g., RIMMFRMAN, supra note 4, 80, 168; Klarman, supra notc 3 , at $474,480$.

153. 744 A.2d 864 (V1. 1999). 
deemphasize these frames and to redefine the same-sex marriage cause as a struggle for civil rights.

In the beginning of the same-sex marriage struggle, litigation served as an important catalyst for subsequent political action. When Hawaii citizens Nina Baehr and Genora Dancel, Joseph Melilo and Patrick Lagon, and Tammy Rodrigues and Antoinette Pregil applied for and were denied marriage licenses, ${ }^{154}$ movement organizations refused to participate in litigation challenging the denial. ${ }^{155}$ Both the ACLU and the Lambda Legal Defense and Education Fund turned down their requests for assistance; ACLU attorneys later cited serious strategic considerations, including a fear of backlash, as justification for the organization's refusal to take the case. ${ }^{156}$

However, in 1993, the Hawaii Supreme Court in Baehr v. Lewin held that denying same-sex couples marriage licenses involved discrimination on the basis of sex and raised the possibility that the state's opposite-sex marriage restriction would be struck down on remand. ${ }^{157}$ The decision itself both reframed debate about same-sex marriage in Hawaii ${ }^{158}$ and

154. The Baehr litigation resulted from the efforts of same-sex couples rather than the work of a state or national gay rights organization. See Jeffrey Schmalz, Ruling Boosts Chances for Gay Marriages in Hawaii, SFATTI.F. POST INTFI IJGENCER, May 7, 1993, at A3.

155. See Paul M. Barrett, I Do/No, You Don't: How Hawaii Became Ground Zero in Battle Over Gay Marriages, WALL SI.. J., June 17, 1996, at A1.

156. Id.

157. 852 P.2d 44, 68 (Haw. 1993). Appealing a trial court decision dismissing their complaint on the pleadings, the three couples' attorney, Dan Foley, offered two frames in his argument to the Hawaii Supreme Court: one based on a fundamental privacy right to marriage, and another based on equal protection doctrine. See id. at 51-52 (describing the petitioners' complaint). Baehr rejected the privacy-right frame proposed by Folcy, refusing to acknowledge that a right to same-sex marriage was "implicit in the concept of ordered liberty, such that neither liberty nor justice would exist if it were sacrificed." Id. at 57 . At trial, the parties and the trial court focused on whether gays were a suspect class, and the trial court found that homosexuals in Hawaii were not a suspect class because they had "not becn relegated to a position of "political powerlessness"" and because Hawaii's marriage restriction did not "burden ... the exercise of the right to engage in a homosexual lifestyle." $I d$. at 53 . By contrast, the Baehr Court described the issue of sexual-orientation discrimination as "irrelevant," framing the question instead as one of discrimination on the basis of sex. See id. at $53 \mathrm{n} .14$. For this reason, the court remanded the cases with instructions to the trial court to apply strict scrutiny in analyzing the state's marriage restriction. Id. at 68 .

158. In Hawaii in the early 1990 s, state organizations also combined natural law and "special rights" arguments in their advocacy. For example, Mike Gabbard, a prominent antigay activist, founded organizations called Stop Promoting Homosexuality Hawaii and Common Sense Now, which described homosexuality as unnatural and illogical. George de Lama, Ilawaii May Lead Way on Same-Sex Marriage, CHI. TRIB., May 15, 1994, at 21. Baehr helped to marginalize some of these arguments in Hawaii and focused in-state debate on the question of the statc's justification for excluding gays from marriage. In April 1994, the Hawaii House of Representatives passed a law explaining that same-sex marriage could be banned because of "concern for the health and well-being of future generations." Bruce 
sparked a framing contest at the national level. ${ }^{159}$ Opponents of samesex marriage fired the first shot in this battle, arguing that the "real issue" for proponents of same-sex marriage was not marriage at all, but rather the legitimacy of homosexuality itself. ${ }^{160}$ In 1994, for example, Robert Knight of the conservative Family Research Council told the San Francisco Chronicle that Baehr should be condemned, because it was "part of the pan-sexual movement's attempt to deconstruct ... morality in the culture."'161

Other New Right groups adopted a frame similar to Knight's. ${ }^{162}$ For example, Reverend Louis Sheldon of the Traditional Values Coalition, a powerful non-denominational church lobby, ${ }^{163}$ criticized Baehr by explaining that "[w]hat [gays] really wanted was acceptance, and that [was] something we [could not] give them."164 In other words, according to activists like Knight or Sheldon, the issue was not about the rights sought by gay couples but about the rights that same-sex marriage would take away from everyone else. As Keith Fournier, the Executive Director of the American Center for Law and Justice, the legal wing of

Dunford, Tourism a Pawn in Hawaii Same-Sex Marriage Baule, PitTsburgh Post GAZLITL, Apr. 18, 1994, at A4. After Baehr, even Gabbard described the issue of same-sex marriage differently, telling the Chicago Tribune that "the whole issue of same-sex marriage [came] down to examining the values of family, and society['s] interest in keeping families strong." De Lama, supra note 158 , at 21.

159. There is an extensive literature on the cvolution of the same-sex marriage struggle in the 1990s. See, e.g., Glokgl CIIAUNCly, WIIY MARRIGAl? T'IIL HISIORY SIIAPING IODAY'S DLBATL OVLR GAY EQUALIT'Y 124-28 (2004); ESKRIDGL, supra note 3, at 32-42 (analyzing the politics of sexuality and same-sex marriage in the late 1990s).

160. For analysis of the New Right opposition to same-sex marriage and to

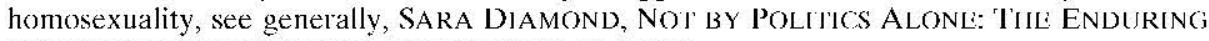
INFLUENCE OF THE CHRISTIAN RIGHT 164-72 (1998).

161. Janc Gross, Hawaii's Pioneering Role on Gay Rights, S.F. CHRON., Apr. 25, 1994, at A7. Gary Bauer, another leader of the Council, echoed this argument, reasoning that legalizing same-sex marriage would harm the "family" and lead to the rejection of "all distinctions based on sex." DI $\Lambda$ MOND, supra note 160, at 170 (quoting Family Research Council, WASH. WATCH, Mar. 26, 1996, at 1).

162. For example, James Dobson of the Colorado-based Focus on the Family described the light against same-sex marriage as a struggle to prevent homosexuals from destroying the institution of marriage. DAN GILGOFF, THE JESUS M $\Lambda$ CHINE: HOW J $\Lambda$ MES DOBSON, FoCUS ON THF FAMII, A, AND EVANGFIICAI, AMFRICA ARE, WINNING THF CUITURF, WAR 11 (2007) (quoting DALE BUSS, FAMILY MAN: T'IIE BIOGRAPIIY OI DR. JAMLS DOBSON 336 (2005)); see also WILLIAM N. ESKRIDGL JR. \& DARRLN R. SPLDALL, GAY MARRIAGL: FOR BETTER OR FOR WORSE? 29-31 (2006) (tracing similar arguments made by conservative congressmen and members of the (hurch of Latter-day Saints).

163. For a current account of the Traditional Values Coalition and its activities, see TraditionalValues.org, About TVC, htlp://www.traditionalvalues.org/about.php (last visited Dec. 19, 2010).

164. Bertha Boxall, Hawaii Justice Opens Door to Legalizing Gay Marriages, L.A. Timls, May 26, 1995, at 1. 
Pat Robertson's Christian Coalition, put it, the issue was not whether gays would be given rights but whether "[h]omosexual marriage" would be allowed to attack the family. ${ }^{165}$

In the later 1990s, opponents like Focus on the Family and the Family Research Council created a defense-of-marriage frame at the same time that Congress was debating a federal Defense of Marriage Act (DOMA) ${ }^{166}$ this frame suggested that the issue in the same-sex marriage struggle was whether straight marriages should be protected or undermined. ${ }^{16}$

Because debate in the late 1990s still turned on the legitimacy of homosexuality, the first national-level, gay rights organizations encouraged their members to hold back any argument based on sexualorientation discrimination. In July 1995, when the newly formed Freedom to Marry Coalition, an umbrella organization for groups advocating same-sex marriage, met to discuss how best to frame the issue, ${ }^{168}$ leaders of the Coalition indicated that a majority of Americans believed, as anti-gay activists argued, that same sex marriage was "not a civil rights issue." 169 Instead of making anti-discrimination claims, the

165. See Di 1 MOND, supra note 160 , at 171 .

166. 28 U.S.C. $\$ 1738 \mathrm{C}(2006)$.

167. See DIAMOND, supra note 160 , at 171-72 (tracing the evolution of defense-ofmarriage claims); see also ESKRIDGL \& SPLDALL, supra note 162, at 29 (tracing the evolution of defense-of-marriage claims). When testifying before Congress in favor of the federal DOMA, Gary Baucr of the Family Rescarch Council cxplained that accepting same-sex marriage would require Congress to "restructure our sexual morality and social system to embrace a system that has never ... been accepted in the world by any major culture." See Defense of Marriage Act: IIearing on S. 1740 Before the S. Judiciary Comm., 104th Cong. 21 (1996) (statement of Gary Bauer, President, Family Research Council); see also Linda Chavez, Another Front in the Culure Wars, DFnvfr Post, July 22, 1998, at B7. Deborah Whyman, a state legislator from Michigan, denounced same-sex marriage as dangerous and "bizarre social experimentation." In defense-of-marriage claims, the central issue remained the legitimacy of homosexuality as a lifestyle and its ability to infect or undermine the majority culturc. See Defense of Marriage Act: Hearing on H.R. 3396 Before the Subcomm. on the Constitution of the H. Comm. on the Judiciary, 104th Cong. 77 (1996) (Statement of Mich. Rep. Deborah Whyman). These were what William Eskridge calls "sedimentary" arguments, claims incorporating past criticism of homosexuality. See William N. Eskridge Jr., No Promo IIomo: The Sedimentation of Antigay Discourse and the Channeling Effect of Judicial Review, 75 N.Y.U. L. RF.V. 1327, 1327-34 (2000). Defense of marriage arguments, like carlier contagion-based claims, implied that permitting gays to marry would somehow contaminate heterosexual marriage and perhaps the greater society. For an example of analysis of contagion-based, anti-gay arguments, see Channeling, supra note 28 , at 523 and William N. Eskridge Jr., Body Politics: Lawrence v. Texas and the Constitution of Disgust and Contagion, 57 U. FI.A. L. RF.V. 1011, 1030 (2005).

168. Freedom to Marry Coalition Meeting Agenda and Notes (July 24, 1995), in The PFLAG Papers [hereinafter PFLAG Papers] (on file with the Division of Rare and Manuscript Collcctions, Corncll University).

169. Leller from Evan Wolfson to Rob Banaszak (July 20, 1995), in PFLAG Papers, 
Coalition urged members to stress that "[b]ecause marriage is a basic ... right and an individual personal choice, ... the State should not interfere with same-gender couples who choose to marry." A similar approach was taken by the Human Rights Campaign, a prominent gayrights political action committee. ${ }^{171}$ In particular, the Campaign advised activists not to make equality-based or civil rights arguments but to argue instead that "[a]dults should be free to choose the person with whom they want to spend their lives."172

\section{Lowering the Cost of Dissent}

For grassroots and regional activists in Vermont, the courts offered a forum where the gay rights movement's definition of the same-sex marriage cause could be challenged, reworked, and supplemented. In 1995, grassroots organizers Beth Robinson and Susan Murray founded a Vermont Freedom to Marry Task Force, ${ }^{173}$ and by 1997, joined Mary Bonauto of the Gay and Lesbian Defenders (GLAD), a New Englandbased regional gay-rights organization, in mounting a constitutional challenge to Vermont's marriage law..$^{174}$

Robinson, Murray, and Bonauto used the courts as a place to redefine the same-sex marriage cause as one involving the equality interests of gays and their wish not to be subjected to sex role stereotypes. At a press conference in November 1998, Bonauto explained that Baker was "about what ... Vermont's guarantees of equality mean for Vermont citizens." following February, Deborah Lashman, an attorney and prominent member of the Vermont Freedom to Marry Coalition, explained that the issue was whether, based on sex stereotypes, the Vermont Constitution allowed "the Legislature to single out a class of families for adverse treatment."

supra notc 168 .

170. Press Release, Lambda Legal, Lambda Urges Religious Leaders to Support

Equality for Same-Sex Couples (Aug. 13, 1998), http:/www.lambdalegal.org/ ncws/pr/ny_19980813_lambda-urges-rcligious-lcaders-to-support-marriagc-cquality.html.

171. See Michael Oreskes, Dinner By Homosexuals Will Aid Political Drives, N.Y. TIMES, Sept. 4, 1982, at 25 (discussing the Campaign's early activities); see also Colman McCarthy, Gay Rights and Gay Acceptance, WASH. POST, Oct. 9, 1982, al A19.

172. Talking Points (Jan. 31, 1996), in PFLAG Papers, supra note 168.

173. See CHAUNCEY, supra note 159 , at 128.

174. See Peter S. Canellos, Vt. Gays Sue for Right to Marry, BoS TON GLObl, July 22, 1997, at B1. A5.

175. Gay Marriage Debate Set in Vermoni Courl, SACRAMfnto BF., Nov. 18, 1998, at

176. Press Release, Vermont Freedom to Marry Task Force, Civil Rights Group 
By partly endorsing the equality-based frame advanced by Vermont Freedom to Marry, Baker helped to redefine the same-sex marriage cause. While rejecting Bonauto's sex-stereotype argument, the Vermont Supreme Court reasoned that the petitioners' sexual orientation, and the public's tolerance of it, had to be considered central issues in the case. ${ }^{177}$ But the court also drew on the frame proposed by Bonauto and Robinson, explaining that the petitioners were entitled to relief as couples, because same-sex couples were "entitled under Chapter I, Article 7, of the Vermont Constitution to obtain the same benefits and protections afforded by Vermont law to married oppositesex couples." 178

\section{Changing Arguments}

The history of the same-sex marriage struggle in the years after Baker shows how courts can, as Robert Cover puts it, "kill" frames, suggesting that one is correct and implicitly dismissing the rest. ${ }^{179}$ When Goodridge, a challenge to a Massachusetts opposite-sex marriage restriction, was pending in the Massachusetts Supreme Judicial Court in 2003 , the equality-based frame used in Baker was only one of several put forth by gay rights activists. After the Supreme Court struck down a Texas sodomy ban that year in Lawrence v. Texas, ${ }^{180}$ Kevin Cathcart of Lambda Legal, a gay rights litigation and education fund, promised that marriage would be the next step in what was a fight for "real equality [for] gay people." ${ }^{\prime 11}$ By contrast, other members of the Freedom to Marry Coalition described the marriage struggle after Lawrence as one for privacy, arguing that, after the decision, "[n]on-gay Americans are coming to understand that... including the police in our bedrooms is wrong." 1182

Denounces Discriminatory Bill (Feb. 1999) (on file with the author).

177. See Baker v. State, 744 A.2d 864, 880 n. 13 (Vt. 1999) (rejecting petitioners' sexdiscrimination claim).

178. Id. at 886

179. Robert M. Cover, Foreword: Nomos and Narrative, 97 HARv. L. RLV. 4, 53 (1983).

180. 539 U.S. $558(2003)$.

181. David Von Drehle, A Debate on Marriage, and More, Now Looms, Wasil. Posi', Jun. 27, 2003, at A1.

182. Evan Wolfson, Liberly, Justice, and Marriage for All, ForwARD, July 4, 2003, at 72 available al http:/www.forward.com/articles/761\%/; see also Readers and Members" Comments on Same-Sex Marriage, PFLAG Newsletter (Summer 2003), in PFLAG Papers, supra note 168 (relating the argument of one PFLAG member that same-sex marriage was an issue of equal protection and equal dignity, the contention of another that marriage was a choicebased right, like abortion, and the assertion of yet another that marriage was an issue of privacy). The Human Rights Campaign also stressed privacy arguments in its July 2003 "Rapid Response Campaign," a program designed to capitalize on a potential victory in 
Goodridge helped to shift the argumentative strategies these advocates adopted. Writing for a four-justice majority, Chief Justice Margaret Marshall explained that Goodridge was both an equalprotection and due-process decision. ${ }^{18: 3}$ However, the Goodridge majority consistently stressed civil- and equal-rights rhetoric in describing the relationship between different constitutional protections. $^{184}$ Although the court did not employ only traditional state equal-protection analysis, ${ }^{185}$ its decision was steeped in equality-based rhetoric, including its assertion that " $[\mathrm{t}]$ he history of constitutional law 'is the story of the extension of constitutional rights and protections to people once ignored or excluded.",186

Goodridge helped change the arguments that defined the national same-sex marriage debate. The Freedom to Marry Coalition first considered the effect of Goodridge on its strategy in November 2003, at a staff meeting on civil marriage. ${ }^{187}$ Most of the arguments drew on the civil-rights and equality-based rhetoric used by the Goodridge Court. ${ }^{188}$ One staff member suggested linking the victories of the "marriage equality movement" and "[o]ther civil rights advances, such as Brown v. Board of Education." In its new campaign against a federal constitutional ban on same-sex marriage, the Human Rights Campaign also borrowed the civil-rights and equality-based rhetoric of Goodridge. ${ }^{190}$ The Campaign claimed that "[s]ettling for anything less than full and equal marriage rights means settling for treatment as second-class citizens." $" 191$

Goodridge. HRC's Rapid Responsc Campaign (July 2003), in PFLAG Papers, supra note 168. Human Rights Campaign members were also told to state that "[t]he decision of whom to marry should be left to individuals - not dictated by the government." Id.

183. Goodridge v. Dep’t Pub. Health, 798 N.E.2d 941 (Mass. 2003).

184. See id. at $956-58,961,966$.

185. See id. at 953.

186. Id. at 966 (quoting United States v. Virginia, 518 U.S. 515, 557 (1996)).

187. Summary of Staff Meeting on Civil Marriage (Nov. 21, 2003), in PFLAG Papers, supra note 168 .

188. Id.

189. Id. Coalition members also bcgan stressing that same-scx marriage was a civil rights issuc that should be supported by racial and cthnic minoritics. For cxample, in 2005, the National Gay and Lesbian Task Force, a gay-rights lobbying and advocacy group and a key member of the Coalition, published a report suggesting that "black gay and lesbian couples actually have more 10 gain on average from the ability to marry." The National Gay and Lesbian Task Force, Black Same-Sex Marriage: Houscholds Report Conference Call (Oct. 6, 2004), in The National Gay and Lesbian Task Force Collection hereinafter Human Rights] (on file with the Division of Rare and Manuscript Collections, Cornell University). 189.

190. See Don't Amend: Gay Marriage Is Our Right (2004), in Human Rights, supra note

191. Id. 
By reshaping one side of movement-countermovement dialogue, Goodridge also encouraged opponents of same-sex marriage to reformulate their arguments against the cause. As we have seen, between 1996 and 2003, opponents of same-sex marriage spoke about what made same-sex couples intrinsically unequal, inferior, or immoral. As Richard Cizik of the National Association of Evangelicals reiterated in 2003, "[w] hat a lot of leaders of the gay community want is for [evangelicals] to stop preaching that homosexuality is a $\sin .^{, 192}$ This, Cizik explained, was a compromise evangelicals would not make. ${ }^{193}$

By reframing the debate, Goodridge helped marginalize some of these arguments. In 2004, as a part of their campaign to have Goodridge overruled or limited in its effect, same-sex marriage opponents in Massachusetts made more comprehensive efforts to change their argumentative strategy. ${ }^{194}$ In May, Reverend Kristian Mineau, one of the leading opponents of Goodridge in Massachusetts, denounced "antigay groups, the homophobic groups" for "discredit[ing]" opposition to same-sex marriage. ${ }^{105}$ Similarly, in the fall of 2006, when the Family Research Council held a rally in Boston for evangelical groups and politicians opposed to same-sex marriage, leaders at the rally did not criticize homosexuality directly. ${ }^{1 \%(6}$ Instead, they joined Tony Perkins of the Council in arguing that the advancement of same-sex marriage threatened religious liberties. ${ }^{197}$

It is worth noting that some state-level decisions following Goodridge shifted the balance of arguments in this way whether or not these decisions also inspired backlash. Perhaps the clearest example here can be drawn from the recent history of Proposition Eight, a state constitutional referendum banning same-sex marriage and overruling the holding in Marriage Cases. ${ }^{198}$ In 2008, in In re Marriage Cases, the

192. See Caryle Murphy, Falwell and Gays Meet but Don't Eat, WASH Post, Oct. 30, 1999, at B1.

193. Id.

194. In March, for cxample, Boston Archbishop Scan O'Malley asked Catholics not to cxpress "anger or vilification of any group of pcople, especially our homoscxual brothers and sisters." Michael Paulson, Archbishop Warns Against Vilifying Homosexuals, Bosion GLOBE, May 14, 2004, at A18.

195. See David D. Kirkpatrick, Gay Marriage Opponents Keep Low Profle for Now, N.Y.'TIMLS, May 17, 2004, at A16.

196. See Michael Paulson, Group to Rally Opposition to Gay Marriage, Boston GLobE, Oct. 15, 2006, at A1.

197. Id.

198. For discussion of Proposition Eight and carly reaction to its success, sce Kornblum, supra note 1, at A3. Since voters passed Proposition Eight in November 2008, the California Supreme Court rejected, in Strauss v. Horton, a state constitutional challenge to its validity. See Strauss v. Horton, 207 P.3d 48, 48 (Cal. 2009); John Schwartz, Ruling Upholds California's 
California Supreme Court struck down the state's opposite-sex marriage restriction, basing its decision on state equal-protection doctrine and emphasizing the close ties between the civil rights and same-sex marriage movements. ${ }^{199}$

That the decision produced a well-organized backlash is welldocumented. $^{200}$ However, after the decision, state-level organizations such as Protect Marriage that led the campaign for Proposition Eight did not as often emphasize that homosexuality was unnatural or deserving of condemnation. ${ }^{201}$ Nor did the groups frequently stress defense-of-marriage arguments or claims about the unique benefits of heterosexual marriage. ${ }^{202}$ Instead, Protect Marriage and national groups like the National Organization for Marriage framed same-sex marriage as a threat to religious liberty and the freedom of parents to control the education of their children. Protect Marriage explained that Proposition Eight was necessary, because public "schools [would] be required to teach students that gay marriage [was] the same as traditional marriage." 20.3 Another state-based group argued in support of Proposition Eight, because "[c]hurches may have their tax exempt status ... if they publicly oppose same-sex marriage." ${ }^{204}$ The National Organization for Marriage, a prominent anti-gay group, told its activists to "avoid at all costs" emphasizing a "ban [on] same-sex marriage" instead of stressing claims about religious liberty and public school education. ${ }^{205}$ Between 1999 and 2006, even though roughly the same proportion of Americans believed that homosexuality was acceptable (between about $62 \%$ and $56 \%$ ), ${ }^{206}$ the argument that gay couples were unequal and immoral no longer played as central a role in the same-sex marriage debate after Goodridge.

Ban on Gay Marriage, N.Y. TIMFs, May 27, 2009, at A1.

199. See In re Marriage Cases, 183 P.3d 384, 444-51 (Cal. 2008).

200. In the clcction immcdiatcly following Marriage Cases, for cxample, statc constitutional bans on same-sex marriage succeeded in Florida, Arizona, and California. See John Christoffersen, Connecticut Same-Sex Couples Now Can Marry, Housron CIIRON., Nov. 13, 2008, at A3.

201. See WhatisProp8.com, What is Proposition 8?, http://www.whatisprop8.com (last visited Dec. 20, 2010).

202. See id.

203. ProtectMarriage.com, Why Proposition Eight?, http://www.protectmarriage .com/about/why (last visited Dec. 20, 2010).

204. WhatisProp8.com, supra note 201.

205. NationForMarriage.org, Marriage Talking Points, http://www.nationformarriage .org/site/c.omL2KeN0LzH/b.4475595/k.566A/Marriage_Talking_Points.htm (last visited Dec. $20,2010)$.

206. See Gallup.com, Gay and Lesbian Rights, available at http:/www.gallup.com/ poll/1651/gay-lesbian-rights.aspx (last visited Jan. 10, 2011). 


\section{Changing Alliances}

As Goodridge shifted the arguments made by each side, the decision also created new alliance-making opportunities. In the years before Goodridge, the gay-rights movement framed the same-sex marriage debate as either an employment-discrimination issue or as a question of constitutional privacy. While GLAD and the Massachusetts Gay and Lesbian Political Caucus (MGLPC) focused on passing a bill recognizing same-sex relationships for the purpose of state-employee insurance, ${ }^{207}$ activists argued that domestic partnerships were "an issue ... about equal pay for equal work." GLAD, and their allies also stressed that same-sex marriage was an issue of constitutional privacy. ${ }^{209}$ When a state Defense of Marriage bill was filed, GLAD and MGLPC expressed some approval of a competing bill filed by libertarian organizations that: (1) abolished restrictions on same-sex marriage and plural marriages; and (2) eliminated any laws punishing "bedroom crimes." 10 Partly for this reason, in 2000, the Massachusetts Freedom to Marry Coalition counted as "existing coalition partners" several unions, including the National Association of Social Workers, as well as the Libertarian Party. ${ }^{211}$ Organizations such as the NAACP, the Hispanic Bar, or Japanese Association that campaigned for the rights of racial or ethnic minorities were only "prospect[ive]" allies. ${ }^{212}$

When Goodridge helped to reframe the same-sex marriage cause as one involving civil rights, the same-sex marriage movement was able to win different allies. Although a number of historically AfricanAmerican churches had come out against Goodridge and its constitutional justification for same-sex marriage in the winter of $2004,{ }^{213}$ other civil rights leaders, like Julian Bond of the NAACP and members of the National Black Justice Coalition, joined the debate in support of

207. See Domestic Partnership Efforts in Cities and Towns (Mar. 25, 1998), in The Massachusetts Gay and Lesbian Political Caucus Papers, (on file with the Northeastern University Archives, Northeastern University) [hereinafter Caucus Papers].

208. See, e.g., id.

209. See, e.g., The Religious Coalition for the Freedom 10 Marry, Massachusetts Declaration of Support for the Freedom of Same-Gender Couples (2000), in Caucus Papers, supra note 207.

210. The Freedom of Marriage and Freedom of Bedroom Acts (2000), in Caucus Papers, supra note 207.

211. See, e.g., Memorandum from Mary Bonauto (Jan. 25, 1998), in Caucus Papers, supra note 207.

212. Id.

213. Michael Paulson, Black Clergy Rejection Stirs Gay Marriage Backers, BosION GLOBL, Feb. 10, 2004, at B1. 
"marriage equality." 214 In December 2004, Coretta Scott King and other members of the civil rights movement began publicly supporting the same-sex marriage movement and its claims of constitutional equality. ${ }^{2.5}$ In the winter of 2005, Mark Leno, another prominent civil rights leader and pastor, proposed a same-sex marriage bill in the California Legislature. ${ }^{216}$ When asked why he supported the measure, Leno explained that the bill should be endorsed by anyone "calling for equality."

\section{Changing Policy Possibilities?}

These shifting arguments in the same-sex marriage debate also may have helped to produce a change in popular opinion. Of course, a considerable amount of the shift in opinion on same-sex marriage may be attributable to generational turnover and longer-term political trends. ${ }^{218}$ Nonetheless, in the wake of the California Supreme Court's opinion in In re Marriage Cases, for example, California's Field Poll showed that there had been a dramatic increase in support for same-sex marriage among racial minorities between 2006 and 2008..$^{21 \%}$ In May 2006 , only $35 \%$ of Latinos expressed support for same-sex marriage. ${ }^{220}$ By May 2008, after the decision of Marriage Cases, support among Latinos rose as high as $49 \% .^{221}$ After the intensive get-out-the-vote efforts sponsored by the Mormon and Catholic Churches, only 53\% of Hispanics voted for Proposition Eight. ${ }^{222}$ Even among AfricanAmericans, In re Marriage Cases may have prompted an increase in approval of same-sex marriage. Through 2006, almost $80 \%$ of African-

214. See, e.g., Tara Dccring, Black Gay Rights Advocales Rally, CHI. TRIB., May 21, 2004, at 7; Lynctte Clemetson, Both Sides Courl Black Churches in the Baule Over Gay Marriage, N.Y. T'IMLs, Mar. 1, 2004, at A1.

215. See, e.g., id.

216. Black Leaders Join Leno in Backing Gay Unions, SuN RLP., Jan. 6, 2005, at 3.

217. Id.

218. Mark DiCamillo \& Mlikvin Filld, 'lill Filld POll 2 (May 28, 2008), http:// www.field.com/fieldpollonline/subscribers/Rls2268.pdf (arguing that younger subjects were more likely to support same-sex marriage in California, as were more politically liberal and less religious citizens) [hereinafter FIELD POLL, May 2008].

219. See Mark DiCamillo \& Mlrvin Filizd, T'ill Filidd POll (July 18, 2008), http:// www.field.com/fieldpollonline/subscribers/Rls2278.pdf; FILLD P'OLL, May 2008, supra note

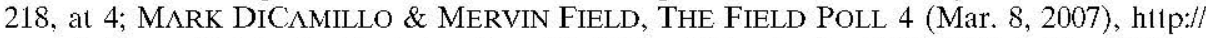
www.ficld.com/ficldpollonline/subseribers/Rls2223.pdf [hereinafter FIFI.D POI.I, Mar. 2007].

220. FILLD POLL, Mar. 2007, supra note 219, at 4.

221. Fifi.d POI., May 2008, supra note 218, at 4.

222. See Karl Vick \& Ashley Surdin, Most of California's Black Voters Backed Gay Marriage Ban, WASII. POSI, Nov. 7, 2008, at A3. 
Americans polled in California opposed same-sex marriage. ${ }^{223}$ By 2008 , when Californians voted on Proposition Eight, only $70 \%$ voted in favor. ${ }^{224}$ However slowly views are changing, there has been a striking shift in opinion among African-Americans in a very brief period after Marriage Cases.

The series of decisions from Baker to Marriage Cases helped to marginalize arguments that deemphasized sexual-orientation discrimination. Similarly, these decisions helped to downplay contentions that homosexuality was immoral or that it posed a danger to "traditional" marriage. Over time, as these decisions shifted the terms of debate, the potential allies available to the gay rights movement changed as well. These decisions did this work, not as litigation's critics would predict, by convincing the public to accept the legitimacy of a movement's complaint. Instead, these decisions affected the way that citizens made sense of the legal and political issues involved in the samesex marriage struggle.

\section{REEXAMINING THE VALUE OF LITIGATION}

In studying the history of the same-sex marriage and abortion struggles, we might be tempted to assume that the terms of discussion have remained relatively stable over time. Nonetheless, the case studies considered here suggest that this would be a mistake. Because litigation's critics ignore the ways in which judicial decisions redefine movement causes, their theories discount important advantages of going to court. As the history studied here suggests, litigation sometimes offers movements framing opportunities that might not be available through ordinary politics.

First, unlike public protest or political lobbying, litigation may sometimes allow movement members to offer a rich range of competing or complementary frames. Before Roe, as we have seen, pro-choice leaders like Lader and Nellis cited strategic reasons for deemphasizing women's-rights claims in the political arena. Through the use of amicus briefs, advocates like Stearns and Zarky effectively used the litigation of Roe to advance alternative women's-right frames that were not

223. See FIELD POLL, Mar. 2007, supra note 219, at 4.

224. FILLD POLL, May 2008 , supra note 218 , at 3 . The shift in approval of same-sex marriage among Caucasians in the same period was much less significant. Through 2006, $53 \%$ of Caucasians supporled same-sex marriage. FIELD POLL, Mar. 2007, supra note 219, at 4. By July 2008, when Caucasians were asked about an anti-same-sex-marriage amendment, $54 \%$ stated that they would vote against such an amendment, a much less significant shift than was observed among African-Americans in the same period. FiLLd P'OLL, May 2008, supra note 218 , at 3 . 
sometimes thought to be strategically wise in the political domain. ${ }^{225}$ Moreover, Sarah Weddington, counsel for Jane Roe, took advantage of liberal pleading rules to offer both physicians'-rights and feminist frames of the abortion issue. ${ }^{226}$

Similarly, we have seen that the courts offered grassroots and regional gay rights groups a forum to challenge and supplement the frames offered by national-level groups in the same-sex marriage struggle. In the political arena, as we have seen, national gay rights organizations trained activists to speak with a single voice, discouraging lobbyists and political operatives from offering alternative equality- or anti-discrimination-based frames. Beth Robinson, Mary Bonauto, and Vermont Freedom to Marry used the litigation of Baker to promote an alternative, anti-discrimination frame.

Second, by comparison to direct action protest, litigation may sometimes be a less strategically risky way to publicize a movement's frame. A movement may pay a high price if it adopts alternative strategies for winning media attention, such as recruiting a charismatic leader or staging dramatic protests. ${ }^{27}$ Because the media cover controversial judicial opinions, especially those on social issues and civil rights, the courts may offer a less risky way of publicizing a movement's frame. $^{22 .}$ By attracting controversy, a judicial decision will focus media attention on a court's work product. ${ }^{229}$ When the public turns its attention to a different set of issues, the court's decision may effectively change the definition of a movement's cause.

The history considered here also suggests that there is a good deal at stake when the definition of a grievance shifts. First, this history suggests that a judicial decision may help to shift the balance of arguments that defines a debate. We have seen that Roe deemphasized population control claims and helped to privilege contentions about women's abortion rights. The decision encouraged advocates to argue, as NARAL operatives were instructed, that "women should be free to

225. See supra notes 124,126 and accompanying text.

226. For a sample of the broad range of frames offered by counscl for Jane Roe in Roe v. Wade, sce GARROW, supra note 117, at 501-02.

227. See, e.g., supra notes $88-89$ and accompanying text.

228. See Vai.firif J. Hof.kstra, Pubi.ic Rfaction to Supremf. Court Dficisions 56 (2003) (cxplaining that the media focus most often on "civil rights and civil libertics cases"); (GRABLR, supra note 91 (arguing that the media pay a good deal of attention to controversial issues).

229. See SI.OTNICK \& SFGAI, supra note 92, at 10, 13 (arguing that the media focus on the substance of an opinion rather than on the process through which the Court arrived at a result). 
make their own decisions regarding childbearing and contraceptive use." ${ }^{230}$ Similarly, as we have seen, a series of state decisions helped to raise the prominence of equality-based claims about same-sex marriage. Because of decisions like Goodridge, national groups that once told members not to mention "civil rights" later told activists to argue that "[s]ettling for anything less than full and equal marriage rights means settling for treatment as second-class citizens." ${ }^{231}$

Moreover, as the terms of a debate change, different coalitionbuilding opportunities may become available to each side as well. After Roe, as we have seen, the pro-choice movement was able for the first time to build an effective partnership with civil rights leaders like Jesse Jackson and Ted Kennedy. Similarly, as Goodridge shifted the definition of the same-sex marriage cause, the gay rights movement was able for the first time to win important civil rights allies like Julian Bond and Coretta Scott King.

Thus, the history of the abortion and same-sex marriage struggles suggests that there is much more at stake in the definition of a movement's cause than might be supposed by litigation's critics. First, as the social meaning of a movement's grievance changes, the policy opportunities available to that group may narrow or expand. For example, we have seen how the changing definition of abortion helped the pro-choice movement win allies in Congress who helped to fight against strict Medicaid abortion bans. Second, the history considered thus far implies that the evolving definition of a cause may reshape popular opinion. Over time, after decisions like Goodridge and Marriage Cases helped to redefine the same-sex marriage cause, support for the practice among some racial minorities may have increased. ${ }^{232}$ Similarly, there is evidence that, as Roe deemphasized population control arguments, African-Americans became more likely to support legalized abortion. ${ }^{23}$

Litigation's critics assume a model of the relationship between law and social change fundamentally different from the one described here. This model hypothesizes that law primarily reflects popular mores. Building on this premise, the model next assumes that social change occurs only when popular approval of a practice increases.

230. Mary Ziegler, supra note 135, at 317 (quoling N $\Lambda$ TIONAL ABORTION RIGHTS LFAGUJ, LFGAI. ABORTION: A SPFAKFR'S AND DFBATFR'S NOTFBOOK 29 (1978).

231. Don't Amend: Gay Marriage Is Our Right (2004), in Human Rights, supra note 189; see, e.g., supra text accompanying note 190.

232. See supra notcs $217-218$ and accompanying text.

233. See supra note 148 and accompanying text. 
Consequently, litigation's critics reason that litigation is valuable only when it suppresses outliers or cleans up after any major social change has already taken place.

However, the history considered here suggests that this model is oversimplified. And if the model of social change assumed by these scholars is incomplete, there may be reason to question their normative conclusions. Of course, the history studied here does not suggest that litigation will always be a wise strategic choice for a movement or countermovement with limited resources. But constitutional framing does suggest that it may still be worthwhile to seek change through litigation. Although we may be aware of reasons not to rely on judicial decisions, we should be equally careful not to blind ourselves to the opportunities still available in the courts.

\section{CONCLUSION}

Theory to date has increasingly shaken confidence in litigation as a tool for social change. Although scholars criticize change-oriented litigation for different reasons, they work from a shared model of the relationship between legal and social change. This model first proposes that law merely reflects social mores. For this reason, the next hypothesis holds that, by striking down already unpopular laws, the courts act only after social change has taken place. Finally, the model suggests that social change begins not when the courts issue a decision but only when the public begins accepting the legitimacy of a movement's cause.

As we have seen from the history of the abortion and same-sex marriage struggles, this is not the only way we should describe the relationship between legal and social change. Contrary to the reflectionist hypothesis, the courts not only mirror popular opinion but also serve as a place where movements challenge the existing definitions of their causes and where new definitions of movement grievance emerge. Contrary to the clean-up hypothesis, constitutional framing shows that the courts implement already popular remedies and reshape the terms of the debates and the coalitions participating in them. And contrary to the cause-acceptance hypothesis, constitutional framing suggests that social change may begin both when the public begins accepting the justness of a movement's cause and when that cause is labeled differently.

What, then, in the end, is the lesson of framing for social movements working for constitutional change? It is perhaps that we should not expect too much from constitutional litigation, but neither should we 
expect too little. For issues of constitutional law like abortion or samesex marriage can often be defined in a number of different ways, and these definitions may provoke varying reactions. Whether we support a cause will depend in large part on what we understand that cause to be. 